\title{
A Knowledge Concept Map: Structured Concept Analysis from Systematic Literature Review
}

\author{
Philip Sisson ${ }^{1}$ and Julie J.C.H. Ryan ${ }^{2}$
}

\begin{abstract}
The purpose of this article is to present a mental model of knowledge as a concept map as an input to knowledge management (KM) investigations. This article's extended knowledge concept map can serve as a resource where the investigation, development, or application of knowledge would be served with a broad mental model of knowledge. Previously unrelated concepts are related; knowledge concepts can sometimes be expressed as a range, i.e., certainty related states: view, opinion, sentiment, persuasion, belief, and conviction. Extrathesis is identified as a potential skill level higher than synthesis, and associated with the concepts: discovery, institution, insight (the event), revelation, or illumination that precedes innovation. Qualitative methods were used to gather and document concepts. System engineering and object analysis methods were applied to define and relate concepts. However, the theoretical sampling and theoretical saturation methods applied do not guarantee all appropriate concepts have been identified. Given the breadth, depth, and dimensionality of concepts of knowledge, later researchers may add additional concepts. This article provides evidence of additional things people know, an alternative to psychology's acquaintanceship, understanding and placement of newer categorizations of knowledge in relation to older ones, and suggests that ranges for knowledge terms exist. This article extends the 2015 paper on this topic by: 1) taking a deeper look into epistemological terms and relationships, 2) providing contextual definitions, 3) suggesting extrathesis as an idea beyond synthesis, 4) updating the concept map; and 5) providing new insight on the overloaded knows including adding an eleventh know. It provides a much more solid basis for KM investigations than typical presentations, providing a broad understanding of knowledge that is beneficial. Keywords: knowledge; concept map; knowledge concept map.

\footnotetext{
1 Philip Sisson, Ph.D. Candidate, The George Washington University, 5010 Larno Drive, Alexandria, VA, USA, 22310, e-mail: sissonp@aol.com.

2 Julie J. C. H. Ryan, D.Sc., National Defense Institute University, 300 5th Ave SW, Suite 183H, Washington, DC 20319, e-mail: julieryan@julieryan.com.
} 


\section{INTRODUCTION}

Recurring themes that resonate in business, the media, and academia, affirm that we are in the "Age of Knowledge," that knowledge management $(\mathrm{KM})$ is important, and that both individuals as well as organizations need to continually learn to improve their knowledge base to remain relevant. What tends to be glossed over in these discussions is the question of what knowledge is, and furthermore how to acquire it.

There are whole discourses in philosophy on what is knowledge which tend toward arcane arguments about justified true beliefs and how such beliefs might be formed. Operationalizing these philosophical concepts prove to be difficult, primarily because the philosophical debates are less about utility and more about theory. Thus, an increasing chasm between traditional philosophy and practitioners has developed.

Partitions of knowledge trace back to Aristotle's five virtues (techne, episteme, phronesis, sophia, and nous) (Parry, 2008). How-we-know breakdowns were explored in the 20th century (Stroll, 2013), although they trace back to 1 BC (Leff, 1983). Nichols (2000) summarized a KM perspective ("explicit, implicit, [and] tacit" and "declarative and procedural knowledge") (pp. 3-4). Holsapple and Joshi (2004) present a web of numerous knowledge attributes. The authors' developed knowledge concept map is important because it unloads overloaded terms about what we know, and relates the old and new "knows" to each other, as well as a wide list of previous unrelated, or poorly related, concepts, in a single visual.

As Stroll (2013) suggests, the article first "[studies] uses of "knowledge" in everyday language;"' (the nature of knowledge, para. 3) - "by example, 'who, what, when, where, why, and how' (Pompper, 2005, p. 816)" (Sisson \& Ryan, 2015, p. 1028). This article then looks at the antecedents of these forensic knows (Wilson \& Ibrahim, 2011, p. 132) and moves on to the epistemological basis of some of them, identifying know-valid and know-basis in the process. Other concepts are developed by discussing epistemological beginnings, psychology's contributions, a deeper look into the "knows" of, and knowledge management (KM) contributions to knowledge categorization. "The presented concept map relates diverse concepts such as mental processes, reasoning, justification, Gardner's multiple intelligences, Bloom's Taxonomies, scales and measures of proficiency, and certainty, as well as other topics" (Sisson \& Ryan, 2015, p. 1027). Putting management concepts in perspective to each other allows people to often see separately addressed subjects (such as validity and propositional states, Bloom's taxonomy, and competency terms like journeyman) in relation to each other, perhaps opening new ideas on how to use them. 
Eleven "types of knowns ... plus subcategories for some of them are named" (Sisson \& Ryan, 2015, p. 1028) permitting their use without term-concept overloading. Know-why now has the new tool Option Outlines ${ }^{\mathrm{TM}}$ available to document (Lewis, 2015b). Extrathesis is suggested as an idea beyond synthesis. As postulated, extrathesis could have profound implications in understanding knowledge creation (intuition), upon which significant innovation and subsequent entrepreneurship depends.

This article expands upon "What do we know - building a knowledge concept map" (Sisson \& Ryan, 2015) verbatim, in much of the presented material with specific material quoted and cited, in block quotes, and, in some cases, new ideas are integrated with verbatim extracts. In the last case, the new material will be set off with brackets or italics. Minor changes in punctuation and grammar are not noted. Also, the choice of paragraph style is sometimes based on reducing the complexity of citation to improve readability.

\section{METHODOLOGY}

To address existing and new ideas about what we know, multiple methods were used following qualitative research, concept analysis (systems architecting), and systems thinking (Senge, Kleiner, Roberts, Ross \& Smith, 1994) approaches. Qualitative approaches to explicating and categorizing the components of knowledge were iteratively applied in identifying and examining different knowledge concepts. The goal of the investigation is to create a mental model of knowledge that incorporates more knowledge related concepts in a single visual. Knowledge analyzed as an object (object analysis) (rather than as "a state of mind," an access condition, capability (Alavi \& Leidner, 2001, p. 109), social action (Crane, 2013), or KM view of knowledge as a process (Serenko \& Dumay, 2015, p. 410)) was selected as the dominant presentation method, although enabling action is shown.

The initial words selected "represent knowledge [terms, their] attributes, and related terms that were drawn from a list of over a thousand candidate KM [domain] terms" (Sisson \& Ryan, 2015, p. 1028). They were the basis for further theoretical sampling. Identified concepts were informally coded, relationships were established, and then the concepts were distributed in the evolving concept map. Five basic attributes for knowledge were identified and subsequently extended to accommodate information technology oriented attributes, such as those identified in Holsapple and Joshi's (2004) web of knowledge attributes. New concepts such as influencers, and where knowledge is located (embodied, embrained, etc.), were positioned in the 
map because the authors think ideas like these are important and needed to be addressed.

Knowledge valuation, knowledge as assets, and intellectual capital topics, are not specifically included. Redefinition and extension of the location terms by personal KM (PKM) researcher Schmitt (2015) were only noted, similarly with Lewis's (2015c) Symbiotic Table of Knowledge ${ }^{\mathrm{TM}}$. Both ideas merit mentioning but further consideration is not critical to this overall visualization.

The theoretical sampling and theoretical saturation methods applied do not guarantee all appropriate concepts have been identified. Given the breadth, depth, and dimensionality of concepts of knowledge, later researchers may add additional concepts.

\section{LITERATURE REVIEW}

\section{The old knows and epistemological beginnings}

Knowledge [, understanding,] ... enables capability for action (Peter F. Drucker in The New Realities, cited by Stankosky, 2003). Enabling action traces back to Aristotle's téchné leading to poiesis and phrónésis leading to praxis - action [(Marquardt, 2002; Schwartz, 2011)]. ... It is represented in "facts (including generalizations) and concepts" (Gregory, 2004, knowledge) and in people is "the psychological result of perception and learning and remembering" (Thinkmap, 2012-2017, knowledge) (Sisson \& Ryan, 2015, p. 1028).

Knowledge as representations of the knows resides in many artifacts. It is fairly easy to see hunters shooting deer with arrows in the Lascaux Cave Hunting Painting - know-how. Observers can see a picture of Capistrano with the swallows arriving, and as a result know that birds return annually, but; we do not know what birds visualize (if it is visual) (know-where). The picture could also represent know-when to people. Perhaps the Ankh is an unremembered map to the Garden of Eden (Sisson, personal communication, 2014); see Figure 1. Whether the Lascaux Cave painting is meant to represent know-what or know-how, if the picture of swallows generates a recognition of know-where, or if the Ankh was first a map to the garden of Eden-not a "sacred emblem symbolizing life" (Darvill, 2008, ankh; Merriam-Webster, 2013-2017, ankh), fertility (Ankh, 2016), or a key to "the gates of death onto immortality" (Magalis, 2005, p. 5116) - is in the mind of the observer. 


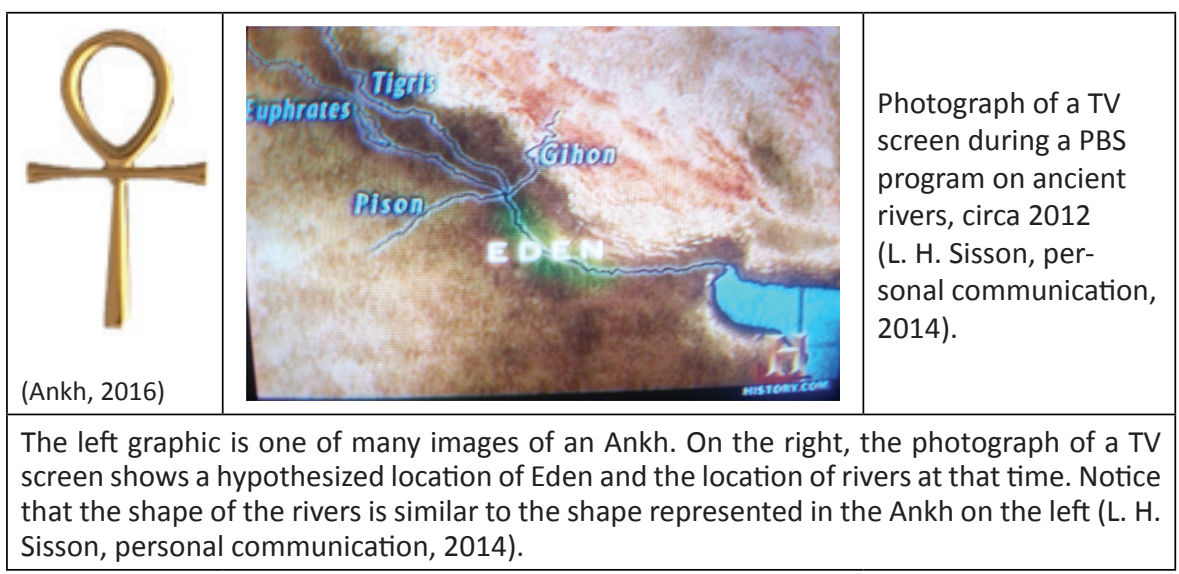

Note: sources as indicated.

Figure 1. The Ankh as a potential map to the Garden of Eden

The earliest writings of humankind also reveal an interest in understanding how we know. One of the first documented knowledge managers was Imhotep, a famous intellectual and architect of Egypt, living in the 27th century BCE. He was known for his organization and harnessing of knowledge in areas as diverse as medicine, architecture, and agriculture (Encyclopaedia Britannica academic, 2012-2016, Imhotep). One of the most famous early philosophers, Sun Tzu, who lived in the $5^{\text {th }}(\mathrm{Li}, 2012$, p. 437) or $4^{\text {th }}$ century BCE, applied the lessons of knowledge management to warfare (Bellamy, 2001, Sun-Tzu) and is widely quoted to this day (The Sonshi Group, 2015). The Greeks developed the concept of the Academy (Kidd, 2006, p. $171)$ to explore knowledge, in the fourth century BCE, producing scholars such as Plato. It is from the latter that we get many of the concepts upon which the current philosophy of knowledge discourse is founded.

Aristotle presented "five virtues of thought" (Téchné, Phrónésis, Noûs, Epistémé, and Sophía) which can be mapped to knowhow, experience, intuition, truth (know-that) (Schwartz, 2011, pp. 40, 42-45) and basic truths (theoretical wisdom) (Feldman \& Ferrari, 2005, p. 485). Accepting Plato's definition of knowledge as a "justified true belief," (Blackburn, 2008 (2016), p. 270, Gettier examples; Conee \& Feldman, 2006) reveals a need for validity (know-valid as something one knows) and raises the idea of how one knows it is justified (know-basis).

Over the millennium other philosophers have investigated knowledge resulting in suggestions of what [it] is and claims by 
others [of what] it is not. "Much of epistemology has arisen either in defense of, or in opposition to, various forms of skepticism" (Klein, 2014, Skepticism; Sisson \& Ryan, 2015, pp. 1028-1029).

Table 1 summarizes the authors' perception of general relationships between some of these epistemological viewpoints, followed by Table 2 with stipulated definitions (as explanations).

Know-that, who, when, where, why, and how "have been explored in detail, especially since the beginning of the 20th century" (Stroll, 2013, epistemology). Most of these terms match Hermagoras of Temnos's (1 BC) list of "a constellation of circumstances" ... "often expressed in the form of ... questions" (Leff, 1983, pp. 28-29). The terms are common to news writing (forensic or straight news) (Pompper, 2005, p. 816)) and in criminal investigations as "situational based explanations" (Wilson \& Ibrahim, 2011, pp. 130-132; Sisson \& Ryan, 2015, p. 1028).

Thus, in modern terms, we find ourselves discussing the same issues plaguing the ancients. Today, however, we are in the context of a technological underpinning that has revolutionized the development, communication, and archiving of that which feeds knowledge: information.

\section{Psychology contributions}

Histories of psychology and philosophy began to diverge in the mid-nineteenth century, when "psychologists came to regard themselves as engaged in a fully fledged science" (Heil, 2005, epistemology and psychology). "Psychology acknowledges three categories of knowledge: declarative knowledge, procedural knowledge, and acquaintanceship knowledge. Declarative and procedural knowledge relate respectively to know-that and know-how (Colman, 2009-2016, declarative knowledge and procedural knowledge)" (Sisson \& Ryan, 2015, p. 1029).

Acquaintanceship knowledge is knowledge of "people, places, and things." and "This class of knowledge was discussed by the Welsh philosopher Bertrand (Arthur William) Russell (1872-1970) in The Problems of Philosophy (1912) and is poorly understood in psychology" (Colman, 2009-2016, acquaintanceship knowledge). However, Thomas Nagel's example of "a bat's knowing what it was like to experience its echo-locatory senses as an example of consciousness" (Van Gulick, 2011, concepts of consciousness, section 2, para. 5) suggests another term: know-like. Dancers also know-like in how they move (Sisson \& Ryan, 2015, p. 1028). Those examples fit in with Russell's "knowledge by acquaintance is 'what we derive from sense'" (Russell per Gregory, 2004, knowledge by acquaintance, and knowledge by description) and may be a missed opportunity to understand acquaintanceship better in terms of know-like (Sisson \& Ryan, 2015, p. 1032). 
Table 1. Summary of relationships in selected epistemological viewpoints

\begin{tabular}{|c|c|c|c|c|}
\hline \multicolumn{3}{|c|}{ Mental (Sensory Induced) } & \multicolumn{2}{|c|}{ Non-Mental (Observed in Actions) } \\
\hline \multicolumn{3}{|c|}{ Occurrent (Aware of) } & \multicolumn{2}{|c|}{ Dispositional (Shown in Behavior) } \\
\hline \multicolumn{5}{|c|}{ Basis } \\
\hline \multicolumn{3}{|c|}{ Perceived, Sense Experience } & Innate ${ }^{A}$ & Hypothesized \\
\hline \multicolumn{3}{|c|}{ Empiricism } & \multicolumn{2}{|c|}{ Rationalism } \\
\hline \multicolumn{3}{|c|}{$\begin{array}{c}\text { A posteriori; Observation (including introspection, } \\
\text { feelings }{ }^{\mathrm{B}} \text { ), experiments }{ }^{\mathrm{C}} \text {, or experience }{ }^{\mathrm{D}} \text {. Acquired } \\
\text { through sense-data }{ }^{\mathrm{E}} \text {. }\end{array}$} & $\begin{array}{l}\text { a priori }^{\mathrm{F}} \\
\text { (incl./ intuition } \\
\end{array}$ & $\begin{array}{l}\text { Reasoning }{ }^{\mathrm{H}} \\
\text { (Thinking, } \\
\text { reflection, etc.) }\end{array}$ \\
\hline \multicolumn{5}{|c|}{ Creation } \\
\hline \multicolumn{3}{|c|}{ Sources } & Inference & \\
\hline $\begin{array}{l}\text { Revela- } \\
\text { tion }\end{array}$ & Intuition & \multicolumn{2}{|c|}{ Induction } & duction \\
\hline \multirow{3}{*}{$\begin{array}{l}\text { Devine } \\
\text { disclosure }\end{array}$} & \multirow{3}{*}{$\begin{array}{l}\text { Rational } \\
\text { insight }^{\mathrm{K}}\end{array}$} & Cause to effect & Effect to cause & \\
\hline & & From premises & $\begin{array}{l}\text { From observations } \\
\text { (facts) }\end{array}$ & \\
\hline & & $\begin{array}{l}\text { "particular to } \\
\text { general" }{ }^{\mathrm{L}}\end{array}$ & $\begin{array}{c}\text { "particularizing from } \\
\text { the general" }\end{array}$ & \\
\hline \multicolumn{5}{|c|}{ Justification } \\
\hline \multicolumn{2}{|r|}{ Evidence } & \multicolumn{2}{|c|}{ (logical propositions) } & liabilism \\
\hline \multicolumn{5}{|c|}{ Certainty / Certitude } \\
\hline \multicolumn{5}{|c|}{ Skepticism } \\
\hline
\end{tabular}

Adapted based on the Indiana Philosophy Ontology Project (InPhOrmers, 2014)

\footnotetext{
A (Brown, 2005, innate ideas). ${ }^{\text {B }}$ (Pike, 2005, p. 2778). C (Colman, 2009-2016, empirical). ${ }^{D}$ (Colman, 2009-2016, a posteriori; Heery \& Noon, 2008, empiricism). ${ }^{\mathrm{E}}$ (Lacey, 2005a, empiricism). ${ }^{\mathrm{F}}$ (Brown, 2005, innate ideas). ${ }^{G}$ (Lacey, 2005b, rationalism). ${ }^{\mathrm{H}}$ Lewis (2013) assets there are only 8 Degrees of Reason ${ }^{\mathrm{TM}}$ (p. 143). ' Including mash-ups, artificial smartness (Foxwell, 2013; Kelly, 2014a, 3. Better Algorithms, para. 10; 2014b, When and Where ... , para. 7). ${ }^{~}$ (Markie, 20131.1 Rationalism, para. 2). ' (Cohen, 2005, induction). "Another name for this is 'generalization from the particular'” (Last, 2007, induction; J. Tiles, 2004). ${ }^{\mathrm{M}}$ (Last, 2007, deductive reasoning).
}

Psychologist's broader interests include "behaviour and mental experience" (Colman, 2009-2016, psychology). The elements of mental and cognitive processes under review in the literature sometimes list different elements. For this article, mental processes mean cognition (thinking) processes, "affect (emotion)" states, "conation or volition (striving)" factors (Scott \& Marshall, 2009-2015, cognition (cognitive)), and sensing processes - "whether conscious or unconscious" (Chandler \& Munday, 2011, cognition (cognitive processes)). Figure 2 shows these as inputs to understanding/ knowledge. They are positioned in the upper left corner of the knowledge concept map. Volition factors and affective states influence knowledge "creation" as an entity's knowledge influences an individual's perception 
and mental processes (Bennet, Bennet \& Avedisian, 2015, p. 1; Schwandt \& Marquardt, 2000, p. 734). Schwandt's Organizational Learning Systems Model contains similar ideas (Schwandt \& Marquardt, 2000); see upper right, left of legend.

Table 2. Explanation of epistemologically related terms

\begin{tabular}{|c|c|c|c|c|}
\hline Term & Definition, Exam & ple, Perspecti & e or Historical Sour & \\
\hline Acquired & $\begin{array}{l}\text { "All human knowledge is derived } \\
\text { from experience" (Quinton, Quin- } \\
\text { ton, \& Fumerton, 2013). }\end{array}$ & Experience & $\begin{array}{l}\text { John Locke (1632-1 } \\
\text { ner (1904-90) }\end{array}$ & 704); B.F. Skin- \\
\hline A Priori $^{A}$ & $\begin{array}{l}\text { "Independent of experience;" B } \\
\text { reasoned from axioms (Oxford } \\
\text { English Dictionary, 2011-2017, } \\
\text { a posteriori). }\end{array}$ & $\begin{array}{l}\text { Innate; } \\
\text { Intuited; } \\
\text { Logical }\end{array}$ & $\begin{array}{l}\text { Albert Of Saxony ( } \\
\text { Immanuel Kant (17 }\end{array}$ & $\begin{array}{l}316-1390) ; \\
24-1804) ; \ldots\end{array}$ \\
\hline A Posteriori & $\begin{array}{l}\text { Reasoned "from effects to } \\
\text { causes, from experience and not } \\
\text { from axioms" (Oxford English Dic- } \\
\text { tionary, 2011-2017, a posteriori). }\end{array}$ & $\begin{array}{l}\text { Observation; } \\
\text { Experiential } \\
\text { (phrónésis) }\end{array}$ & & \\
\hline Behavior & $\begin{array}{l}\text { "Behavior refers ... to easily observ } \\
\text { Collins (1993), "behavior-specific a } \\
\text { which is not essentially situated" ( }\end{array}$ & $\begin{array}{l}\text { able activities' } \\
\text { ction is decont } \\
\text { 108). }\end{array}$ & $\begin{array}{l}\text { (Doorey, 2004, p. } 3 \\
\text { extualizable. It is the }\end{array}$ & $\begin{array}{l}\text { 275). According to } \\
\text { enly form of action }\end{array}$ \\
\hline Certainty & $\begin{array}{l}\text { Indubitability (Reed, 2011, } 2 . \\
\text { Conceptions of certainty, para. } \\
\text { 2) "Knowledge is radically differ- } \\
\text { ent from certitude and neither } \\
\text { concept entails the other" (Refer- } \\
\text { encing Wittgenstein, Stroll, 2013, } \\
\text { Knowledge and Certainty, para. 4). }\end{array}$ & Certitude & Ludwig Wittgenste & in (1889-1951) \\
\hline $\begin{array}{l}\text { Certainty / } \\
\text { Certitude }\end{array}$ & $\begin{array}{l}\text { Certainty/certitude "imply the abse } \\
\text { - certainty with evidence; certitude } \\
\text { certainty, certitude). }\end{array}$ & $\begin{array}{l}\text { ence of doubt } \\
\text {, conviction, } p\end{array}$ & $\begin{array}{l}\text { about the truth of } \mathrm{sc} \\
\text { erhaps purely on be }\end{array}$ & $\begin{array}{l}\text { lief (Allen, 2008, } \\
\text { liething" }\end{array}$ \\
\hline $\begin{array}{l}\text { Construc- } \\
\text { tionism }\end{array}$ & Knowledge (meaning) is constructe & d (Bodner, 19 & 36; Lowenthal \& Mu & th, 2008). \\
\hline $\begin{array}{l}\text { Declarative } \\
\text { Knowledge }\end{array}$ & $\begin{array}{l}\text { "Awareness and understanding of } \mathrm{f} \\
\text { contrast to knowing how" (Colman }\end{array}$ & $\begin{array}{l}\text { factual informa } \\
\text { 2009-2016, d }\end{array}$ & $\begin{array}{l}\text { tion about the worl } \\
\text { eclarative knowledg }\end{array}$ & $\begin{array}{l}\mathrm{d}-\text { knowing that in } \\
\text { e). }\end{array}$ \\
\hline Description & $\begin{array}{l}\text { "What kinds of mental content, if a } \\
\text { edge" (Husserl per Stroll, 2013, De } \\
\text { 2). "Descriptions focus on 'a single } \\
\text { Rodgers, } 2013, \text { p. } 850 \text { ) }\end{array}$ & $\begin{array}{l}\text { any, ought to cc } \\
\text { scription and J } \\
\text { thing' (What is }\end{array}$ & $\begin{array}{l}\text { unt as knowl- } \\
\text { ustification, para. } \\
\text { it?)" (Whetten \& }\end{array}$ & $1858-1989$ \\
\hline $\begin{array}{l}\text { Disposi- } \\
\text { tional }\end{array}$ & $\begin{array}{l}\text { "Dispositional knowledge, as the te } \\
\text { a propensity, to behave in certain v } \\
2013 \text {, Occasional ...). }\end{array}$ & $\begin{array}{l}\text { erm suggests, } \mathrm{i} \\
\text { Nays in certain }\end{array}$ & $\begin{array}{l}\text { a disposition, or } \\
\text { conditions" (Stroll, }\end{array}$ & Behavior \\
\hline
\end{tabular}




\begin{tabular}{|c|c|c|c|}
\hline \multirow{2}{*}{$\begin{array}{l}\text { Term } \\
\text { Empiricism } \\
\text { (knowledge } \\
\text { sources) }\end{array}$} & \multicolumn{3}{|c|}{ Definition, Example, Perspective or Historical Source } \\
\hline & $\begin{array}{l}\text { "All knowl- } \\
\text { edge is } \\
\text { based on } \\
\text { experience } \\
\text { derived from } \\
\text { the senses" } \\
\text { (Stevenson, } \\
\text { 2010-2017, } \\
\text { empiricism). }\end{array}$ & $\begin{array}{l}\text { Sensed; Percep- } \\
\text { tions }\end{array}$ & $\begin{array}{l}\text { Hume, Locke, Mill (Buchanan, 2010-2016, empiri- } \\
\text { cism) (1632-1873) }\end{array}$ \\
\hline \multicolumn{4}{|c|}{ 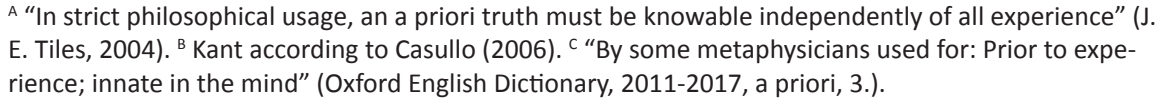 } \\
\hline Empiricism & \multicolumn{3}{|c|}{$\begin{array}{l}\text { In philosophy, "[empiricism is] the theory that all knowledge is based on experience de- } \\
\text { rived from the senses" (Stevenson, 2010-2017, empiricism); "direct observation, experi- } \\
\text { ments, or experience" (Heery \& Noon, 2008, empiricism). "Knowledge, or the materials } \\
\text { from which it is constructed, [is based] on experience through the traditional five senses" } \\
\text { (Lacey, 2005a, empiricism); through "experience, which involves two logical levels, sensa- } \\
\text { tion and reflection" (Darity, 2008, p. 578). }\end{array}$} \\
\hline Evidence & \multicolumn{3}{|c|}{$\begin{array}{l}\text { In this article, evidence is "something that furnishes or tends to furnish proof;" "an out- } \\
\text { ward sign: indication, token" (Merriam-Webster, 2013-2017, evidence, 1b \& 1a). }\end{array}$} \\
\hline Experience & \multicolumn{3}{|c|}{$\begin{array}{l}\text { In this article, experience is "the sum total of the conscious events that make up an indi- } \\
\text { vidual life" (Merriam-Webster, 2013-2017, experience, 5. a) and "the events that make up } \\
\text { the conscious past of a community or nation or humankind generally" (Merriam-Webster, } \\
2012-2016 \text {, experience, 3. b.). }\end{array}$} \\
\hline Inference & \multicolumn{3}{|c|}{$\begin{array}{l}\text { Inference can be seen as the process, "premises and conclusion that represent a process } \\
\text { of inferring or that form the determinants of a belief" (Merriam-Webster, 2013-2017, } \\
\text { inference, 3). }\end{array}$} \\
\hline \multirow[t]{2}{*}{ Innate } & \multicolumn{2}{|c|}{$\begin{array}{l}\text { "Present in the mind, in } \\
\text { some sense, from birth" } \\
\text { (Stroll, 2013, innate and } \\
\text { acquired knowledge). }\end{array}$} & $\begin{array}{l}\text { 428/427-348/347 BCE); Descartes (1596-1650); Noam } \\
\text { ky (1928-) }\end{array}$ \\
\hline & \multicolumn{3}{|c|}{$\begin{array}{l}\text { Innate knowledge is "an idea that is inborn, rather than being learned through experi- } \\
\text { ence" (Colman, 2009-2016, innate idea) (Blackburn, } 2008 \text { (2016), innate ideas); "ideas } \\
\text { that exist in the mind without having been derived from previous experience" (Brown, } \\
\text { 2005). }\end{array}$} \\
\hline Intuition & \multicolumn{3}{|c|}{$\begin{array}{l}\text { "In philosophy, [intuition is] the power of obtaining knowledge that cannot be acquired } \\
\text { either by inference or observation, by reason or experience" (Encyclopaedia Britannica } \\
\text { Academic, 2012-2016, Intuition). }\end{array}$} \\
\hline Justify & \multicolumn{3}{|c|}{$\begin{array}{l}\text { In this article, to justify is to "show to be reasonable or provide adequate ground for;" } \\
\text { "show to be right by providing justification or proof" (Thinkmap, 2012-2017, justify). }\end{array}$} \\
\hline $\begin{array}{l}\text { Justifica- } \\
\text { tion }\end{array}$ & \multicolumn{3}{|c|}{$\begin{array}{l}\text { "What kinds of belief (if any) can be rationally justified" ... "what one ought ideally to } \\
\text { believe" (Stroll, 2013. description and justification, para. 3). }\end{array}$} \\
\hline Knowledge & \multicolumn{3}{|c|}{$\begin{array}{l}\text { "Justified true belief" (Blackburn, } 2008 \text { (2016), Gettier examples); “(1) if A knows that p, } \\
\text { then p is true, and ( } 2 \text { ) if A knows that p, then A cannot be mistaken; ..." (Stroll, 2013skepti- } \\
\text { cism, para. 3). }\end{array}$} \\
\hline
\end{tabular}




\begin{tabular}{|c|c|}
\hline Term & Definition, Example, Perspective or Historical Source \\
\hline $\begin{array}{l}\text { Mental } \\
\text { State and } \\
\text { Knowing }\end{array}$ & $\begin{array}{l}\text { "Knowledge is a state of mind" (awareness). Awareness } \\
\text { "Knowing is a mental state akin to, but different }\end{array}$ \\
\hline Perceived & $\begin{array}{l}\text { In psychology, perception is "the process or product of organizing and interpreting sensa- } \\
\text { tions (sensory data from external objects or events) into meaningful patterns" (Chandler } \\
\& \text { Munday, 2011, perception (perceiving)). "Perception depends upon the sense organs } \\
\text { possessed by the animal, and the interpretation that is placed upon incoming sensations } \\
\text { by the brain" (McFarland, 2006, perception). }\end{array}$ \\
\hline
\end{tabular}

Procedural "Information about how to carry out sequences of operations-knowing how in contrast Knowledge to knowing that" (Colman, 2009-2016, procedural knowledge).

\begin{tabular}{|c|c|c|c|c|}
\hline $\begin{array}{l}\text { Mental } \\
\text { Processes }\end{array}$ & \multicolumn{4}{|c|}{$\begin{array}{l}\text { For this article, mental processes are cognition (thinking) processes, volition factors, and } \\
\text { affective states (Scott \& Marshall, 2009-2015, cognition (cognitive)), and sensing pro- } \\
\text { cesses. }\end{array}$} \\
\hline $\begin{array}{l}\text { Nonmental } \\
\text { conditions }\end{array}$ & $\begin{array}{l}\text { "Knowing is tied to the capacity } \\
\text { to behave in certain way" (Stroll, } \\
2013 \text {, Mental and Nonmental, } \\
\text { para. 3). }\end{array}$ & $\begin{array}{l}\text { As obser } \\
\text { (behavio }\end{array}$ & $\begin{array}{l}\text { rved in actions } \\
\text { or) }\end{array}$ & $\begin{array}{l}\text { Wittgenstein } \\
(1889-1951)\end{array}$ \\
\hline Occurrent & \multicolumn{3}{|c|}{$\begin{array}{l}\text { "Knowledge of which one is currently aware" } \\
\text { (Stroll, 2013, Occasional ...). }\end{array}$} & \\
\hline \multirow[t]{2}{*}{$\begin{array}{l}\text { Rational- } \\
\text { ism }\end{array}$} & $\begin{array}{l}\text { "The ultimate } \\
\text { source of human } \\
\text { knowledge is the } \\
\text { faculty of reason" } \\
\text { (Stroll, 2013, Ratio- } \\
\text { nalism and Empiri- } \\
\text { cism). }\end{array}$ & \multicolumn{2}{|c|}{ Reason (Thinking) } & eibniz (1596-1716) \\
\hline & $\begin{array}{l}\text { In philosophy, rationalism is "the } \\
\text { knowledge, or claims that reason } \\
\text { certainty in knowledge" (Oxford E }\end{array}$ & $\begin{array}{l}\text { trine or } \\
\text { her than } \\
\text { ish Dictic }\end{array}$ & $\begin{array}{l}\text { theory that er } \\
\text { sense experie } \\
\text { onary, 2011-2 }\end{array}$ & $\begin{array}{l}\text { he role of reason in } \\
\text { foundation of } \\
\text { alism, 2. a.). }\end{array}$ \\
\hline
\end{tabular}

Reliabilism Reliabilism is, "in traditional epistemology, what makes a belief justified, being a matter of the believer's rationality and responsibility, must lie within his 'cognitive grasp'. That is, for a belief to be justified the believer must be aware of what makes it justified" (Bach, 2005).
Revelation Revelation is "the divine or supernatural disclosure to humans of something relating to human existence" (Stevenson, 2010-2017, revelation, 2.).
Skepticism "Skepticism in philosophy refers to the principle that all knowledge, whether sensory or conceptual, is subject to the limitations of the human mind and, thus, unreliable" (Reines, 2007, p. 657). "Scepticism is now the denial that knowledge or even rational belief is pos- sible" (Blackburn, 2008 (2016), scepticism).

Volitional Conation and volition represent "intentional mental occurrence[s]" Shown in Behavior
(Conation) (Ginet, 2006, p. 704) leading to a "conscious adoption by an indi- vidual of a line of action." (Kent, 2007-2016, volition)

Historical annotations based on Encyclopedia Britannica Academic epistemology articles, primarily (Stroll, 2013). 
These ideas lead "to concepts of sensation [(know-like)], perception, remember/retrieve/recognition/recall (Marzano \& Kendall, 2007, kindle 828839, Level 1: Retrieval), think, intuit, reason and know. Know-like is revealed in terms of experiential consciousness (like a bat's echo-locatory senses) (Van Gulick, 2011 2.1)" (Sisson \& Ryan, 2015, p. 1029). The concept map differentiates know-that (description) from know-what (an understanding) and displays nine knows (plus know-why (basis)) showing when, where, why, who, like, and why can be clarifiers of how. In the knowledge concept map, the knows are positioned left and below the knowledge box shown in Figure 2.

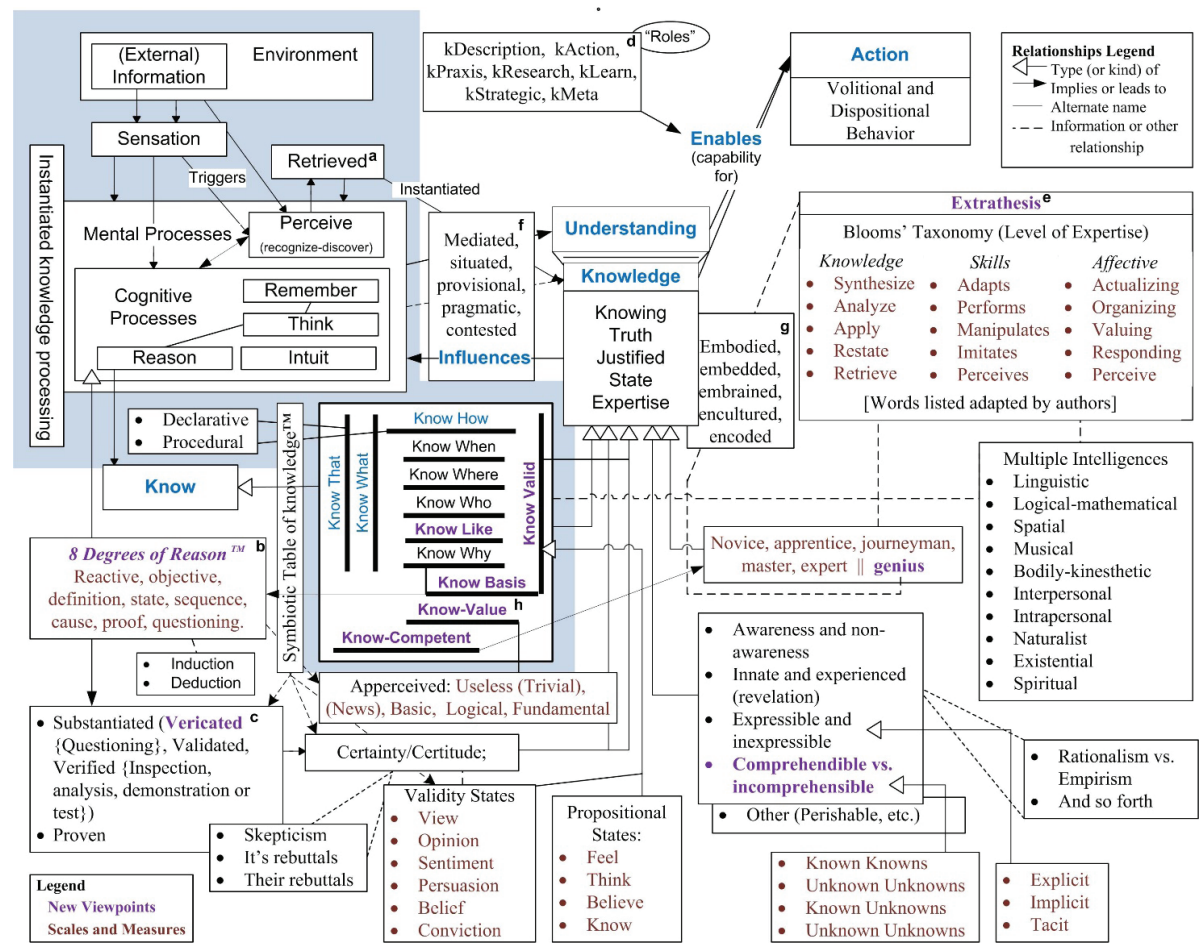

Notes: a) (Marzano \& Kendall, 2007). b) Adapted from (Lewis, 2013). c) (Bennet \& Porter, 2003, p. 477). d) (Bennet \& Bennet, 2008, pp. 410-412). e) (Ryan, Dirienzo, Noteboom \& Sisson, 2015). f) (Blackler, 1995, pp. 1040-1042). g) (Omotayo, 2015, p. 5). h) (Anonymous, 2017).

Figure 2. Location of mental processes and the eleven knows in the concept map highlighted

Source: updated graphic from Sisson \& Ryan (2015, p. 1030). 
Epistemological expertise is know-how - "knowledge of how to do some particular thing; skill, expertise, esp. in regard to a practical or technical matter" (Oxford English Dictionary, 2011-2017, know-how). "More recently, Bloom's Taxonomy (Atherton, 2013; Krathwohl, 2002; [Krathwohl, Bloom \& Masia, 1964]) was developed to help with setting educational objectives that show [an individual's] acquisition of knowledge and skills. The levels in Bloom's three taxonomies can also be viewed as proficiency in cognitive, kinesthetic, and affective capabilities;" perhaps in another respect, kinds of human knowledge that are respectively often named (cognitive), partly named (or macro specified: throw a ball - psychomotor), or gross categorizations (feelings - affective). "Marzano and Kendall (2007) and Fink (2013) address adaptions and extensions of Bloom with an educating, rather than educational, objectives focus." (Sisson \& Ryan, 2015, pp. 1030-1031).

"The medieval guild terms apprentice, journeyman and master speak to levels of competence (Dreyfus \& Dreyfus, 2005)." Ubiquity staff (2005) states, "we do think of expertise as following along a continuum from novice through apprentice, and then journeyman and master." (Sisson \& Ryan, 2015, p. 1030) Dreyfus and Dreyfus (2005), however, list five stages: novice, advanced beginner, competence, proficiency, expertise (expert) (pp. 782-788). Wiig's KM "model-degrees of internalization" (novice, beginner, competent, expert, master) (Dalkir, 2011, kindle location 0933), reverses the order of Dreyfus' labels of expert and master.

The Ryan Research Group suggests that there might be a competence beyond master or expert and a competency level greater than Bloom's synthesis addressing going beyond, extrapolating outside the expert's traditional domain (J. Ryan, J.C.H., Thomas Dirienzo, Anna Noteboom, and Philip Sisson. Ryan Research Group - discussion, spring semester, 2015). Extrathesis is postulated. It results in enlightenment, which in this context is "a state of greater knowledge, understanding, or insight" (Oxford English Dictionary, 2011-2017, enlightenment, 1. a.), not wisdom. Extrathesis has aspects of deep smarts (Brockmöller, 2008; Leonard \& Swap, 2004, p. 55; Ubiquity staff, 2005) (knowledge), deep rationality (Ryan, 2014, section 5), and extraordinary consciousness (Bennet \& Bennet, 2011; Bennet, Bennet \& Avedisian, 2015) to see "the overarching pattern" (Bennet \& Bennet, 2011, p. 12). However, these terms, collectively, are probably more loosely related than truly descriptive of extrathesis. Additionally, the referenced articles attribute them to the domain of the expert and extrathesis, as envisioned, is not limited by the need for high level expertise. The second component ("analytical, creativity, and practical") of "Sternberg's Successful Intelligence Theory", creativity, needs to be looked at with respect to extrathesis as well (Ruban \& Cantu, 2005, pp. 866-867). Gardner's ideas of a "broadly scanning 
mental searchlight" (Waterhouse, 2013, p. 542) is also interesting. Genius (extraordinary, manifested creative or original activity (Merriam-Webster, 2013-2017, genius, 4b)) is a strawman word to express an individual's competency associated with this concept. In the concept map, genius is shown with, but not as an extension of, the master, expert sequence. (Figure 3 shows where expertise levels, Bloom's Taxonomy, and Gardner's multiple intelligences are positioned in the knowledge concept map.)

Gardner's postulated multiple intelligences ("linguistic, musical, logicalmathematical, spatial, bodily-kinesthetic, interpersonal, and intrapersonal," naturalist, and existential intelligence (Nuzzi, 2010, p. 583) and spiritual intelligence - the last rejected by Gardner (Gardner, 2000)). Spiritual intelligence is "able ... to make sense out of the 'ultimate' concerns of human beings, such as the meaning of life and death, or the puzzle of the existence of single individuals in a vast and empty universe" (Plucker \& Esping, 2014, p. 557). "Spiritual intelligence calls for multiple ways of knowing, and for the integration of the inner life of mind and spirit with the outer life of work in the world" (Vaughan, 2002, summary).

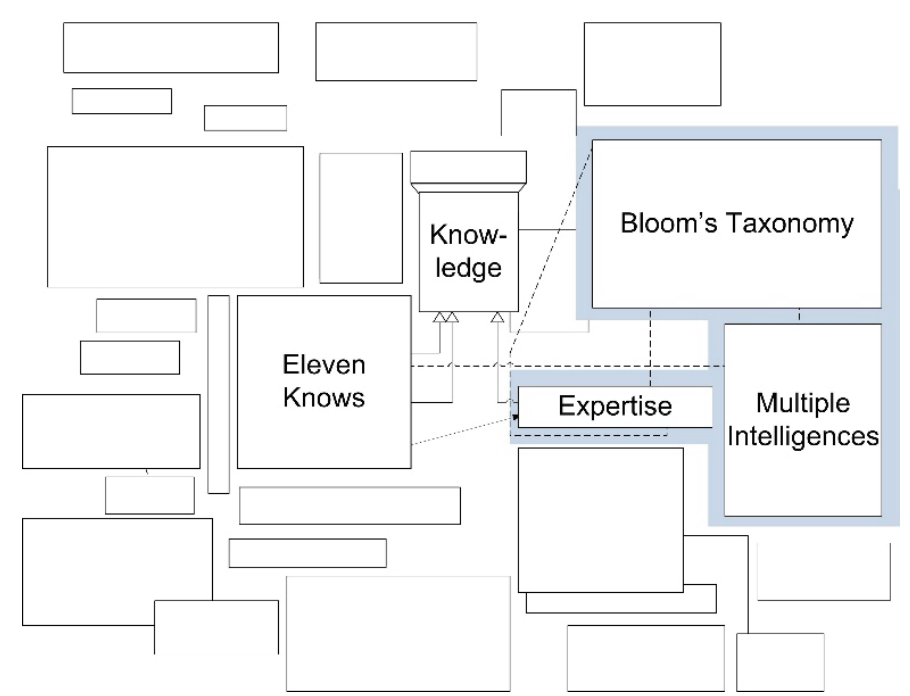

Figure 3. Location of expertise levels, Bloom's Taxonomy of Educational objectives, and Gardner's multiple intelligences in concept map

Source: updated extract (Sisson \& Ryan, 2015, p. 1030).

However, "somewhat to [Gardner's] surprise, 'existential intelligence' qualifies well as an intelligence in light of the eight criteria that [he has] set forth in [his] writings (Gardner, 1993, chap. 4)" (Gardner, 2000, p. 29). For Gardner, "intelligence permits an individual to solve problems and create 
products that are of value within a cultural context" (Ruban \& Cantu, 2005, p. 866). "Neuroscience research has not validated [the idea of] multiple intelligences. ... researchers ... have noted that no neuroscience research had tested the theory of multiple intelligences and that neuroscience research had disconfirmed the existence of the putative separate content processing modules in the brain" (Waterhouse, 2013, p. 543). Regardless, Gardner's ideas are still useful in thinking about knowledge. Österberg (2004) separates Gardner's intelligences as "abilities that explain" "knowing that' or 'knowing how'" (p. 147); notwithstanding, the authors believe that the general relationships shown in Figure 3 are better from a knowledge mental model perspective. In the concept map, "multiple intelligences are shown as related to the [eleven] knows in terms of what each of the intelligences can know and to Bloom's taxonomy as indicators of proficiency in the intelligences" (Sisson \& Ryan, 2015, p. 1031).

\section{DISCUSSION AND FINDINGS}

\section{The Knows}

"Know-that and know-how trace back to Epistémé and Téchné" (Sisson \& Ryan, 2015, p. 1029). Epistémé is know-that (Fantl, 2012), truth/reality. In this context, truth is "the Greek notion of truth as 'correspondence with reality" (Schwarzschild, 2007, p. 162). Sophía is basic truths/theoretical wisdom. Both come from "Theoria - the production of truth" (Calhoun, 2002 , praxis). For this article, they are viewed as know-that in terms of the knows. Ein-Dor (2011), in his "Taxonomies of Knowledge," discusses knowabout ("what drug is appropriate for an illness") as an example of declarative knowledge, but the term is not added as a separate row category in table 3 , since it is a statement of fact, know-that. He places "tacit-explicit, individualsocial, procedural-declarative, commonsense-expert, and task-contextual" as opposing dimensions (see his figure 1, p. 1497). In the discussion, he also lists categories: "Procedural: Know-how," "Causal: Know-why," "Conditional: Know-when," and "Relational: Know-with." Ein-Dor excludes three "the categories recognized in (Alavi \& Leidner, 2001, p. 113) ... conditional, relational, and pragmatic" as "not generally recognized as basic dimensions of knowledge." (Ein-Dor, 2011, pp. 1491-1499).

Blackler (1995), however, in categorizing knowledge ties know-that from Ryles (1949) and know-about from James (1950) together, but in terms of "conceptual skills and cognitive abilities." Similarly, Blackler ascribes embodied, action oriented, partly explicit knowledge to Ryles (know-how) and James (knowledge of acquaintance) (pp. 1035, 1023-1024). In looking at 
knowing as an activity state, Blackler (1995) brings out knowing as mediated [constantly changing], situated [interpreted within contexts], provisional [and developing], pragmatic [driven by conceptions], and contested (pp. 1040-1042). This group of terms in the knowledge concept map resides in the area from mental processes, leading to understanding, and supports the idea that knowledge is constructed each time it is used (Bodner, 1986; Lowenthal \& Muth, 2008).

Conditional is shown as a subcategory of know-when in this article's model because of its time implication. Relational is included in this article's model as connectivity ("cause-and-effect" - know-why (Fink \& Disterer, 2011, p. 651). Pragmatic knowledge, mentioned as "useful knowledge for an organization," (Alavi \& Leidner, 2001, p. 113; Ein-Dor, 2011, table, p. 1492) is relevance in Table 3. Know-with may be a category of know-how. It also has connotations of connectivity already included in know-why (Ein-Dor, 2011, pp. 1492, 1496-1497). "Holsapple and Joshi (2004, pp. 597-598) use many of the same words as Ein-Dor." Their "web of knowledge attributes" are mode: tact, explicit; type: reasoning, procedural, descriptive; perishability: none, rapid; accessibility: public, private; applicability: local, global; immediacy: actionable, latent; orientation: domain, relational, self (p. 598, figure 596). "Their perspective seems more knowledge as represented in information systems oriented and revealed no new knows;" although, the web of knowledge and knowledge dimensions are alluded to in the knowledge concept map as "other" differentiators of knowledge's state attribute. (Sisson \& Ryan, 2015, p. 1029).

Like know-how, "know-what partly comes from Hermagoras ('what resources? (quibus adminculis)') (Leff, 1983, pp. 28-29); on the other hand, know-what is sometimes used to mean 'clear recognition of the objective of a selected course of action' (Merriam-Webster, 2013-2017, know-what) or 'knowing which information is needed' (Marquardt, 2002, pp. 141-142)" (Sisson \& Ryan, 2015, p. 1029). From an organizational learning perspective, Marquardt (2002) also stipulates for organizational learning: 1) "'Know how:' Knowing how information must be processed." 2) "Know why:' Knowing why certain information is needed." 3) "Know where:' Knowing where to find certain specific information." 4) "'Know when:' Knowing when certain information is needed" (pp. 141-142). "This [paper pictures] know-what as being able to have a mental image of a situation - an understanding" (Sisson \& Ryan, 2015, p. 1029). 
Table 3. What we know - the knows

\begin{tabular}{|c|c|c|}
\hline $\begin{array}{l}\text { Type of } \\
\text { knowing }\end{array}$ & Sources & Definition, example, or source \\
\hline Know-that & $\begin{array}{l}\text { Epistémé } \\
\text { Psychology }\end{array}$ & $\begin{array}{l}\text { "Seems to denote the possession of specific pieces of information, and } \\
\text { the person who has knowledge of this sort generally can convey it to } \\
\text { others" (Martinich \& Stroll, 2013. The nature of knowledge, para. 3); } \\
\text { declarative knowledge (Colman, 2009-2016, knowledge). }\end{array}$ \\
\hline Know-what & Greeks & $\begin{array}{l}\text { Know-what is "structural knowledge, patterns" (Charles Savage per } \\
\text { Green, 2005, slide 16); "something imagined or pictured in the mind" } \\
\text { (Merriam-Webster, 2011-2016, concept, 2.). }\end{array}$ \\
\hline \multirow{2}{*}{$\begin{array}{l}\text { Recitability } \\
\text { of facts }\end{array}$} & Straight News & $\begin{array}{l}\text { Capability to mentally identify supposed facts - "five W's and H (who, } \\
\text { what, when, where, why, and how)" (Pompper, 2005, p. 816). }\end{array}$ \\
\hline & Hermagoras & “With what resources?” (Leff, 1983, pp. 28-29). \\
\hline $\begin{array}{l}\text { Resources } \\
\text { Objective }\end{array}$ & Dictionary & $\begin{array}{l}\text { "Of a selected course of action" (Merriam-Webster, 2013-2017, know- } \\
\text { what); "knowing which information is needed" (Marquardt, 2002, pp. } \\
\text { 141-142). }\end{array}$ \\
\hline Know-who & Greeks & $\begin{array}{l}\text { Know-who is knowledge about "a person, indefinitely or abstractly; } \\
\text { a 'some one"” (Oxford English Dictionary, 2011-2017, who, III. 14. b.). }\end{array}$ \\
\hline Know-where & Greeks & $\begin{array}{l}\text { Know-where is "a sense of place;" do/did something (Charles Savage } \\
\text { per Green, 2005, slide 16); "where to find" (Kazmer, 2002, p. 426; Mar- } \\
\text { quardt, 2002, pp. 141-142); "at this time; now" (Thinkmap, 2012-2017, } \\
\text { where, adverbs) (present) extrapolated to include past and future. }\end{array}$ \\
\hline Know-when & Greeks & $\begin{array}{l}\text { Know-when is time, "a sense of timing" (Altheide \& Snow, 1979, p. 35; } \\
\text { Charles Savage per Green, 2005, slide 16) "the time in which something } \\
\text { is done or comes about" (Merriam-Webster, 2012-2016, when, Main } \\
\text { Entry: when, 1616); is needed (Marquardt, 2002, pp. 141-142); occurs } \\
\text { or occurred. }\end{array}$ \\
\hline Conditional & Research & $\begin{array}{l}\text { "When to prescribe the drug" (Alavi \& Leidner, 2001, p. 113; Ein-Dor, } \\
\text { 2011, p. 1492). }\end{array}$ \\
\hline Know-why & Greeks & $\begin{array}{l}\text { Know-why provides rationale (D. Fink \& Disterer, 2011, p. 651); “for } \\
\text { what reason" (Merriam-Webster, 2013-2017, wherefore) (Lewis, 2015c); } \\
\text { wider context (Charles Savage per Green, 2005, slide 16). }\end{array}$ \\
\hline Motivation & $\begin{array}{l}\text { Volition / } \\
\text { Connation }\end{array}$ & Know-why (motivation) is what triggered the action or inaction. \\
\hline Relevance & $\begin{array}{l}\text { Leadership / } \\
\text { KM / }\end{array}$ & Know-why (relevance) is external; pragmatic (Ein-Dor, 2011, p. 1492). \\
\hline Connectivity & Research & $\begin{array}{l}\text { Know-why (connectivity): "cause-and-effect relationships" (Fink \& } \\
\text { Disterer, 2011, p. 651); “relational: know-with" (Ein-Dor, 2011, p. 1492). }\end{array}$ \\
\hline Basis & $\begin{array}{l}\text { Justification } \\
\text { (Aristotle) }\end{array}$ & $\begin{array}{l}\text { Know-why (basis) is the rationale used for justification; "within [one's] } \\
\text { "cognitive grasp'" (Blackburn, } 2008 \text { ( } 2016) \text {, scepticism) by accepting } \\
\text { authority or using another one of Lewis's } 8 \text { Degrees of Reason }{ }^{\mathrm{TM}} \text { (Lewis, } \\
2015 \text { a). }\end{array}$ \\
\hline Know-how & Téchné & $\begin{array}{l}\text { Know-how is "knowledge of how to do some particular thing; skill, } \\
\text { expertise" (Oxford English Dictionary, 2011-2017, know-how). }\end{array}$ \\
\hline $\begin{array}{l}\text { Know-com- } \\
\text { petent }\end{array}$ & $\begin{array}{l}\text { Medieval } \\
\text { Guilds }\end{array}$ & Knowledge of personal and others (general) level of expertise. \\
\hline
\end{tabular}




\begin{tabular}{|c|c|c|}
\hline $\begin{array}{l}\text { Type of } \\
\text { knowing }\end{array}$ & Sources & Definition, example, or source \\
\hline Know-like & $\begin{array}{l}\text { Sensation } \\
\text { (Nagel) }\end{array}$ & $\begin{array}{l}\text { Know-like is experiential awareness (acquaintanceship knowledge); } \\
\text { familiarity. }\end{array}$ \\
\hline Familiarity & $\begin{array}{l}\text { Acquain- } \\
\text { tanceship }\end{array}$ & $\begin{array}{l}\text { "The state of being well known: the familiarity of the scene" (Australian } \\
\text { Oxford Dictionary, 2004, familiarity). }\end{array}$ \\
\hline Sensation & $\begin{array}{l}\text { Conscious- } \\
\text { ness }\end{array}$ & From the senses. \\
\hline Feelings & $\begin{array}{l}\text { Affective } \\
\text { Domain }\end{array}$ & $\begin{array}{l}\text { "A feeling can be almost any subjective reaction or state" (Waite, Lind- } \\
\text { berg \& Zimmer, 2008. emotion) }\end{array}$ \\
\hline $\begin{array}{l}\text { Categoriza- } \\
\text { tion }\end{array}$ & Gardner & $\begin{array}{l}\text { Naturalist Intelligence: discriminating and classifying (Colman, 2009- } \\
\text { 2016, multiple intelligences; Nuzzi, 2010, p. 585); (not just “found in } \\
\text { nature" per (Nuzzi, 2010). }\end{array}$ \\
\hline $\begin{array}{l}\text { Perception } \\
\text { (potential) }\end{array}$ & $\begin{array}{l}\text { Gardner, } \\
\text { Primal }\end{array}$ & $\begin{array}{l}\text { From Gardner's spiritual intelligence classification (Colman, 2009-2016, } \\
\text { multiple intelligences), chakra (Maxwell, 2009), and paranormal (Gus- } \\
\text { tavsson, 2014, 7. Other Philosophical Work, para 4) feeling. }\end{array}$ \\
\hline Know-valid & Aristotle & $\begin{array}{l}\text { Know-valid is knowing that is "something that is true" (enough/verisi- } \\
\text { militude versus verity (Merriam-Webster, 2013-2017. veracity, truth)); } \\
\text { the veracity (Bennet \& Porter, 2003, p. 477) (or level of veracity). }\end{array}$ \\
\hline Know-value & $\begin{array}{l}\text { Economic } \\
\text { Knowledge }\end{array}$ & $\begin{array}{l}\text { Know-value is being able to assess at least a relative value of the knowl- } \\
\text { edge. Derived from the idea of economic knowledge (Anonymous Re- } \\
\text { viewer, 2017) }\end{array}$ \\
\hline
\end{tabular}

Know-who, know-where and know-when also come from Hermagoras. ... Know-where is more than just a sense of place, it can be a sense of when something was done (the past) or might need to be done (the future). Know-when is obviously time, "a sense of timing" (Altheide \& Snow, 1979, p. 35; Charles Savage per Green, 2005, slide 16) or with regards to a conditional (Alavi \& Leidner, 2001, p. 113; Ein-Dor, 2011, p. 1492).

Know-why, the last of the $5 \mathrm{Ws}$ in news reporting, overall addresses rational. From [a] professional knowledge [perspective,] it is "cause-and-effect relationships" (Fink \& Disterer, 2011, p. 651) or relational (Ein-Dor, 2011, p. 1492) (also connectivity). Citing Quinn, Anderson, and Finkelstein (1996), D. Fink and Disterer (2011) mention care-why (in terms of creativity) which includes "will, motivation, and adaptability for success" (p. 651 \& 652). Dalkir (2011) lists care-why along with "expertise, know-how, [and] know-why" in the third category of tacit properties (, kindle, location 234). L. D. Fink (2013, pp. 3, 5, and 6) has caring as one of her six categories for significant learning. For this article's authors, care-why is more volitional or attitudinal than a type of knowing. The authors view motivational rationale ... as entity specific with relevance more often institutional. Adaptability is something exhibited, not something known. Knowing why-valid [and] know-basis, leads to [Lewis's asserted, only] 8 Degrees of Reason ${ }^{\mathrm{TM}}$. (Lewis, 2012, pp. 113-174; Sisson \& Ryan, 2015, p. 1029). 
Lewis defines "learning as 'the gaining of knowing, satisfied with some degree of reason."' For Lewis, reasoning is a conglomeration of categories, such as how or why it is done, i.e. "what is automatic," "what should be done," or "what one thinks from." (Lewis, 2015a) For this article's knowledge concept map, reason is why. These are several kinds of why - motivation, relevance, connectivity, and basis (see Table 3 ). Some of these map directly to Lewis, others do not. "Lewis dives deep into why with a more exhaustive viewpoint" (Sisson \& Ryan, 2015, p. 1029) (Lewis, 2013, pp. 143-208; 2015a; 2015b; 2015c)

"When talking about know-why it would be good to qualify it [unless the usage is clear as] know-why (basis), know-why (motivation), know-why (relevance) or know-why (connectivity)" (Sisson \& Ryan, 2015, p. 1029).

Know-like was recognized as a category related to [psychology's] acquaintanceship knowledge - "knowledge of people, places, and things, and although [acquaintanceship knowledge] may include declarative knowledge it need not necessarily do so, as when one knows a colour, or a smell, or a face, but cannot state any facts about it" (Colman, 2009-2016, acquaintanceship knowledge). (Sisson \& Ryan, 2015, p. 1029).

The acquaintanceship distinction was made by Bertrand Russell. ... Knowledge by acquaintance is "what we derive from sense", which does not imply "even the smallest "knowledge about", i.e. it does not imply knowledge of any proposition concerning the object with which we are acquainted. For Russell, knowledge is primarily - and all knowledge depends upon - the "knowledge by acquaintance of sensations." ... More recently, theories of perception have blurred Russell's distinction by suggesting that there is no direct knowledge by the senses, but that perceptions are essentially descriptions (though by brain states rather than language) of the object world. This follows from the view that perception is knowledge based and depends upon (unconscious) inference, as suggested in the 19th century by Hermann von Helmholtz and now very generally, if not quite always, accepted. (Per Russell, 1914, Gregory, 2004, knowledge by acquaintance, and knowledge by description)

"Familiarity, sensation, and feelings [ideas] resonate well with the concept of [know-like]" (Sisson \& Ryan, 2015, p. 1029), but are fundamentally different. Thinking about Gardner's naturalist intelligence as an object related intelligence (Nuzzi, 2010, p. 584) brings out the idea of categorization as a category of know-like. Also listed as a potential know-like category, 
is perception from Gardner's spiritual intelligence (Colman, 2009-2016, multiple intelligences).

"Know-valid addresses the [level] of internal certainty or certitude view, opinion, sentiment, persuasion, belief, conviction (Merriam-Webster, 2013-2017, opinion, Synonym Discussion; Merriam-Webster, 2012-2016, opinion)"3 (Sisson \& Ryan, 2015, p. 1029). Stroll (2013) cites Plato in that "knowing is one member of a group of mental states that," according to current theory, "can be arranged in a series according to increasing certitude" (Mental and Nonmental, para. 1). The authors' preferences are reflected in the concept map by propositional states such as feel, think, believe, and know (Atkinson, 2015, para. 3). Perhaps religious scholars would reverse the order of believe and know.

"Know-competent comes from the Medieval Guilds and Bloom's Taxonomies - [the first] as indicators of competence and [the second educational objectives that can be interpreted] as levels of expertise" (Sisson \& Ryan, 2015, p. 1030). In many cases, it is difficult as an individual to assess true competency, but everyone makes competency assessments and decisions regularly in daily life.

For the presented knowledge model, learning, per se, is not a part of knowledge, rather the environment, or preparing to learn, creates opportunities to trigger pattern recognition and start cognitive processes leading to retrieving (Marzano \& Kendall, 2007, kindle 828-839), or creating knowledge. See Figure 4. From a KM systems model perspective, recognize (discover) was identified as a common concept to capture the ideas about an event that includes recognize, discover, find, intuit, illumination, epiphany, revelation, insight (the event), and learning - to a degree. The authors' interim restatement of the levels of Bloom's Taxonomy shows the 1st level of each to be either retrieve or perceive. In fact, considering other parts of the model, each should start with perception.

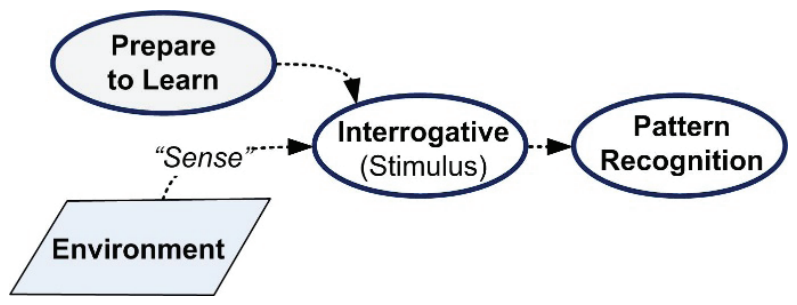

Figure 4. Preparing to learn

Source: modified Sisson \& Ryan (2016a, p. 3, figure 1).

3 The order of these words differs depending which synonym source was consulted. (Merriam-Webster, 2013-2017 opinion. Synonym Discussion; Merriam-Webster, 2012-2016, opinion). 
Organizational learning knowledge creation is similar. Sisson and Ryan's (2016c) poster shows three nominal learning models: for the individual (mental processes), artificial entities (artificial intelligence learning), and organizational learning as typified by Schwandt's Organizational Systems Learning Model (OLSM) (DR Schwandt \& Gundlach, 1992; Schwandt, 1994; David Schwandt \& Marquardt, 2000). The arrows in the poster pointing to all three suggest a common viewpoint may be possible. Or, Schwandt's OLSM may be a general case entity learning model, where the stimulus occurs in the interface, and sense making is analogous to pattern recognition.

\section{Other knowledge management perspectives}

The first KM perspective, Nichols (2000) identifies "explicit, implicit," [and] tacit" and "declarative and procedural knowledge" (pp. 3-4) "dimensions of knowledge" (Nonaka, 1994, p. 16). "Explicit knowledge is that which can be codified or encoded and is represented in certain artifacts" (Bennet \& Tomblin, 2006, p. 293). Implicit "can be articulated but [has not]" (Nichols, 2000, p. 3). "'Tacit' knowledge has a personal quality, which makes it hard to formalize and communicate" (Nonaka, 1994, p. 16); "thoughts that cannot be pulled up from memory and put into words" (Bennet \& Bennet, 2011, slide 33). "Choo (2002), on the other hand, categorise[s] organisational knowledge into tacit, explicit and cultural" (Omotayo, 2015, p. 7). Explicit, implicit, and tacit have aspects of a range (Chaharbaghi et al., 2005, p. 109) [, continuum (Blackler 2002, per Geisler \& Wickramasinghe, 2015, p. 44)]. Cultural is in a different dimension and to these authors fits more with Holsapple and Joshi's "web of knowledge attributes" (2004, p. 598). Collectively, these viewpoints lead to the idea of knowledge being expressible or inexpressible. These concepts are in the center left and lower right corner in figure 5. (Sisson \& Ryan, 2015, p. 1031).

Omotayo (2015) extends Blackler (1995) and others to identify the dimensions of knowledge in terms of where it occurs versus knowledge attributes. Omotayo begins with Blackler who "defines knowledge as taking

4 Omotayo (2015) picks Koenig to address the differences, "Koenig (2012), however, describes this characterization of knowledge into explicit and tacit as rather too simple. He suggests that knowledge is better described as explicit, implicit, and tacit. Explicit means information or knowledge that is set out in tangible form. Implicit is information or knowledge that is not set out in tangible form but could be made explicit, while tacit is information or knowledge that one would have extreme difficulty operationally setting out in tangible form" (p. 7). 
five distinct forms: embodied, embedded, embrained, encultured, and encoded." ${ }^{5,6,7}$

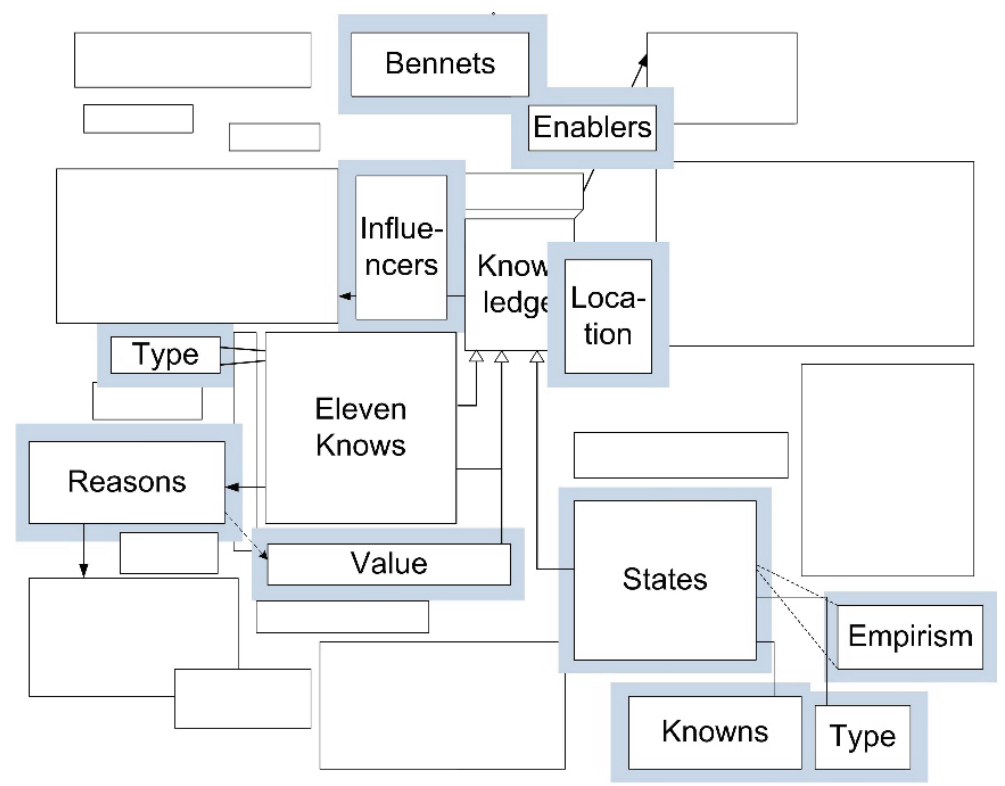

Figure 5. Fanning out from the central concepts to other perspectives

Source: updated extract (Sisson \& Ryan, 2015, p. 1030).

Per Omotayo, embodied is gained through bodily training (Bloom's Psychomotor Domain). Embedded is in "routines and systems," (organizational memory in organizations). Embrained is tacit or implicit; encultured is shared knowledge; and encoded is explicit. "It can be said that organisational knowledge is embodied and embrained in the staff, embedded in routines/ common tasks, encultured among the staff, and encoded in manuals, guidelines and procedures" (p. 5). Hislop, Strati, Yakhef, Davenport and Pusak, Badaracco, Nonaka, Takeuchi, Baloh, et al., Duffy, Polanyi, Koenig, Hibbard, and Martensson are used in his amplification of these ideas (pp. 5-7). Omotayo's where-is-knowledge dimensions are incorporated into the knowledge concept map, but not as knowledge attributes. Blackler's

5 From Collins (1993), Blackler (1995) gets embodied, embrained, encultured (p. 99), the word embedded (p. 98), and encoded, implied by "symbol-type knowledge- that is, knowledge that can be transferred without loss on floppy disks and so forth" (p. 99).

6 Omitting embodied and adding encapsulated, Schmitt (2015, p. 2) mentions these in five, growing to six, pairs associated with "constraints overcome by five co-evolution" sequences: "embodied and embrained (1), encapsulated and encultured (2), encoded and organizational (3), digitized and networked (4), and enclouded and value-chained (5) knowledge with PKM and the World Heritage of Memes Repository (WHOMER) - argued to become the sixth one (p. 2). 7 Green and Ryan's (2005) categories: customer, competitor, employee, information, partner, process, product/service, and technology (p. 47), are all included in Blackler's five. 
other categorizations ("mediated, situated, provisional, pragmatic," and contested (pp. 1040-1042)) are shown as descriptors influencing knowledge construction (Bodner, 1986; Lowenthal \& Muth, 2008). These concepts are to the right and slightly behind the knowledge attributes in the center of the concept map.

Next, the subject of validity is a dominant theme in epistemology. [Verification and validation $]^{8}$ are used in system engineering to check requirements have been met [(verification - "proof of compliance" (NASA SEH, 2007))] and that a system is suitable for its intended purpose (validation ${ }^{9}$ ) (Armstrong, 2011; Krueger, Walden, \& Hamelin, 2011, p. 363). Bennet and Porter (2003, p. 477) offered up another term (vericate) that fits with justification and knowing valid. Vericate means "grounding ... through implicit data and information" (Bennet \& Porter, 2003, p. 477); "to determine the reasonableness or soundness;" (as opposed to verify ("grounded by the explicit)" (Bennet \& Bennet, 2011, slide 4) - partly like validate per systems engineering above. It is accepting a source with "reason to know." That can be "information that requires only an ordinary level of intelligence to infer from it that a certain fact exists, or that there are reasonable and sufficient grounds for its existence. Reason to know implies that a reasonable person may accordingly proceed, relying on the fact's likely existence" (BusinessDirectory. com, 2012-2016, reason to know). Vericate is more known acquaintance - implying checking with someone else (A. Bennet, Bennet, \& Lewis, 2015). Vericate [is somewhat] like Lewis' $8^{\text {th }}$ degree of reasoning - questioning in "ask, and expect an answer" (Lewis, 2015a); however, a hypothetical range of vericate, validate, and verify puts vericate at the beginning. These concepts are shown near the lower left above one legend of the concept map. (Sisson \& Ryan, 2015, p. 1031)

Lewis's (2015c) Symbiotic Table of Knowledge ${ }^{\mathrm{TM}}$ poses two questions... that expand into three question operations, six question types, and twenty base questions about knowledge with descriptive and prescriptive variations. It then categorizes the questions in terms of concise, contextual, consequential, and conceptual answer/knowledge. The concept is placed on the knowledge concept map, positioned between the 8 Degrees of Reason ${ }^{\mathrm{TM}}$

8 After review, the order of these two words is reversed from the order used in (Sisson \& Ryan, 2015).

9 "The Validation Process answers the question of 'Is it the right solution to the problem?" (Defense Acquisition Guidebook, 2013, section 4.3.16). In a semantic view of theories, "good models of the phenomena" (Gimbel, 2011l. 3370) are accurate and representative. Denzin and Lincoln (2011), in their Handbook of Qualitative Research, explore many context specific validation (methods) without defining the term generically; however, validity is about correspondence with reality. 
and the eleven knows, with links to justification, certainty, and validity states. Justification in relation to reasoning, $\mathrm{KM}$, and the scientific method is an area for further investigation (Sisson \& Mazzuchi, 2017).

From their work with the US Navy, the Bennets also developed "a knowledge taxonomy for grouping types of knowledge from the viewpoint of what knowledge is needed to do a particular type of work or take a particular action" (Bennet \& Bennet, 2011, slide 22; Bennet, Bennet \& Avedisian, 2015) - "categories of knowledge". The Bennets' categories do not map cleanly to the [eleven] knows. By example, kDescription, descriptive information (know-that), maps to "what, when, where and who" (Bennet \& Bennet, 2011, slide 22; Bennet \& Bennet, 2008, pp. 408, 410). In the concept map, Bennets' categories are shown related to action as enablers. See, Bennet and Bennet (2008, pp. 409-411) for a discussion of their terms. In terms of the knows, kPraxis and kResearch also point to knowing conditions or causation - know-when (conditional) and know-why (connectivity) but are not shown as explicitly connected in the concept map. These concepts are at the top center.

Rumsfeld is widely credited with the term unknown unknowns [(Ayto \& Crofton, 2011, Unknown unknowns)]. Know-knowns to unknown-unknowns are used in NASA for risk management and project management. The Johari window (1955) (Chandler \& Munday, 2011, Johari window (JW method)) uses similar labels with regards to people. The principle author remembers the terms from, he thinks, a 1967 NASA Summer institute at the University of Southern California concerning project management and development. Two other parties report recalling the terms earlier than Rumsfeld: 1) The Jet Propulsion Lab CKO. 2) A NASA consultant mentioned a Lockheed Martin paper that he is unable to resurrect. Regardless, the terms can be viewed as measures of [comprehensibility] and raise the idea of incomprehensibility as an opposite. These concepts are at near the bottom-right (Sisson \& Ryan, 2015, p. 1031).

Table 4 defines concepts selected from these sources that have been included in this article's model of knowledge. 
Table 4. Additional terms

\begin{tabular}{|c|c|c|c|c|}
\hline Aspect & Source & \multicolumn{3}{|l|}{ Definition or Example } \\
\hline $\begin{array}{l}\text { Expressible / } \\
\text { Inexpressible }\end{array}$ & Psychology & \multicolumn{3}{|c|}{$\begin{array}{l}\text { Declarative or explicit knowledge (words, etc. and sharable) versus } \\
\text { tacit knowledge ("unable to express" (Bennet \& Bennet, 2011, slide } \\
\text { 33; Matthews, 2007-2014, tacit knowledge)) }\end{array}$} \\
\hline $\begin{array}{l}\text { Comprehendi- } \\
\text { ble }{ }^{10} \text { versus }\end{array}$ & Psychology & \multicolumn{3}{|c|}{$\begin{array}{l}\text { "An ability to understand the meaning or importance of something } \\
\text { (or the knowledge acquired as a result)" (Thinkmap, 2012-2017, } \\
\text { comprehension) - know-what (Lewis, 2012, p. 10) versus cannot } \\
\text { figure out }\end{array}$} \\
\hline sible & Deduced & \multicolumn{3}{|c|}{$\begin{array}{l}\text { Incomprehensible is something "that cannot be understood" (Aus- } \\
\text { tralian Oxford Dictionary, 2004, incomprehensible) }\end{array}$} \\
\hline Vericate & Bennets & \multicolumn{3}{|c|}{$\begin{array}{l}\text { Vericate is "to determine the reasonableness or soundness" (Bennet } \\
\text { \& Bennet, 2011, slide 4); "reason to know" (BusinessDirectory.com, } \\
\text { 2012-2016, reason to know) - can be determined by consultation; } \\
\text { (Bennet \& Porter, 2003, p. 477) }\end{array}$} \\
\hline Verify & System & \multicolumn{3}{|c|}{$\begin{array}{l}\text { Verify is "to ascertain or test the accuracy or correctness of (some- } \\
\text { thing), esp. by examination or by comparison with known data, an } \\
\text { original, or some standard; to check or correct in this way" (Oxford } \\
\text { English Dictionary, 2011-2017, verify, para, 4a) }\end{array}$} \\
\hline Validate & & \multicolumn{3}{|c|}{$\begin{array}{l}\text { Validate is to "provide objective evidence that the [solution meets] } \\
\text { its intended use" (Krueger et al., 2011, p. 133); show corresponden- } \\
\text { ce with reality (Gimbel, } 2011 \text { I. 3370) }\end{array}$} \\
\hline & Johari Win- & \multicolumn{2}{|c|}{ "Things we know that we know." } & \multirow{3}{*}{$\begin{array}{l}\text { (Rumsfeld, 2002) per } \\
\text { (O'Connor, 2003, slide 2) }\end{array}$} \\
\hline $\begin{array}{l}\text { - Known- } \\
\text { Unknown }\end{array}$ & $\begin{array}{l}\text { dow (1955) } \\
\text { (Chandler } \\
\text { \& Munday, } \\
\text { 2011, Johari } \\
\text { window (JW }\end{array}$ & $\begin{array}{l}\text { "Events that are } \\
\text { likely to occur based } \\
\text { on historical data" } \\
\text { (Bilbro, 2012, p. 2) }\end{array}$ & $\begin{array}{l}\text { "Something that } \\
\text { you know you } \\
\text { don't know" } \\
\text { ( } 2105 . \text { known } \\
\text { unknown) }\end{array}$ & \\
\hline $\begin{array}{l}\text { - Unknown- } \\
\text { Unknown }\end{array}$ & method)) & $\begin{array}{l}\text { "Events that cannot } \\
\text { be predicted" (Bil- } \\
\text { bro, 2012, p. 2) }\end{array}$ & $\begin{array}{l}\text { "Things we } \\
\text { don't know we } \\
\text { don't know." }\end{array}$ & \\
\hline $\begin{array}{l}\text { - Unknown- } \\
\text { Known }\end{array}$ & $\begin{array}{l}\text { NASA } \\
\text { Knowns }\end{array}$ & \multicolumn{2}{|c|}{$\begin{array}{l}\text { "That which is hidden and known to } \\
\text { me alone." (Johari Window) (Chandler } \\
\text { \& Munday, 2011, Johari window. (JW } \\
\text { method)) }\end{array}$} & $\begin{array}{l}\text { "Things we don't know } \\
\text { we know" (O'Connor, } \\
2003 \text {, slide 2) }\end{array}$ \\
\hline
\end{tabular}

\section{Mental model of knowledge - a concept map}

Figure 6 presents a picture of how the authors see relationships between these different viewpoints.

10 In the meanings in which they overlap, [the words apprehend and comprehend] denote slightly different aspects of understanding. Apprehend means to grasp or perceive a general idea or concept, whereas comprehend means to understand an argument or statement" (Allen, 2008, apprehend, comprehend). 
The environment produces triggers that kick off mental processes that recall, remember, or discover new knowledge - recognizing a pattern that results in some level of understanding (knowledge). Mental, (and cognitive) and sensing processes, and volition factors and affective states are influenced by and influence previously constructed knowledge. Knowledge attributes can be expressed in many dimensions, sometimes as a range within a category. [By example,] opinions and beliefs in the certainty/certitude area could be on a scale from "I feel, I think, I believe to I know" (Atkinson, 2015, para. 3). Certainty with regards to the states can vary from view, opinion, sentiment, persuasion, and belief to conviction (Sisson \& Ryan, 2015, p. 1031).

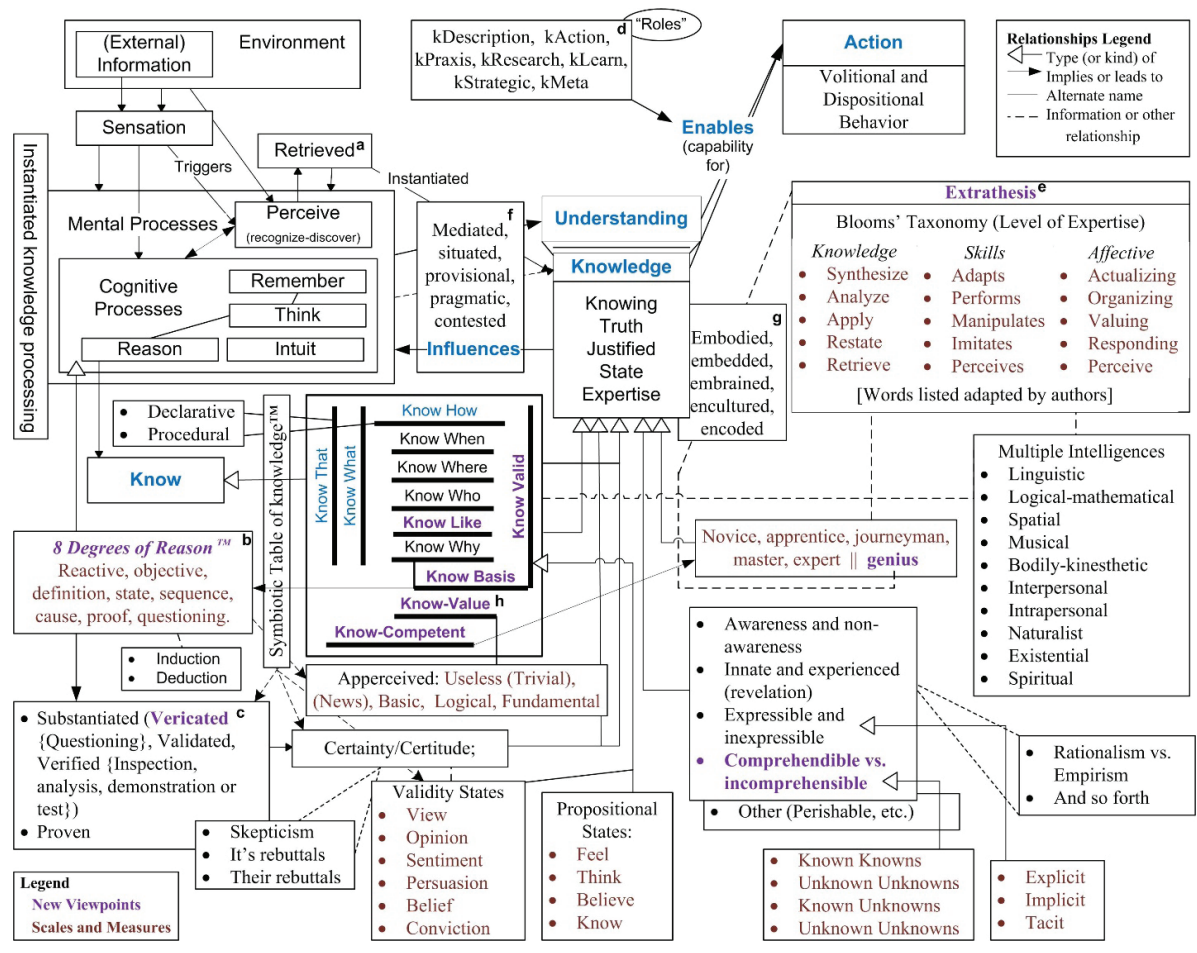

Notes: a) (Marzano \& Kendall, 2007). b) Adapted from (Lewis, 2013). c) (Bennet \& Porter, 2003, p. 477). d) (Bennet \& Bennet, 2008, pp. 410-412). e) (Ryan, Dirienzo, Noteboom \& Sisson, Ryan Research Group, personal communication, spring semester, 2015). f) (Blackler, 1995, pp. 1040-1042). g) (Omotayo, 2015, p. 5). h) (Anonymous, 2017).

Figure 6. Knowledge concept map

Source: updated graphic from Sisson \& Ryan (2015, p. 1030). 
Initially, the authors viewed understanding and knowledge as nearly equivalent. This point of view evolved from definitions of the two, particularly as synonyms. More recently, understanding and knowledge are considered from another viewpoint, as two faces of the same thing (perhaps a yin and yang relationship). At this point, knowledge is beginning to be viewed from the more abstract Epistémé and Sophia perspective, while understanding is being viewed from an outcome of learning perspective.

Thoughts about justified, true beliefs (two attributes in Figure 7), for most people, are not regular, formal occurrences in daily life; yet, people act on knowledge based on internal, often unconscious, assessments (propositional states) of its apperceived value (know-value (Anonymous, 2017)), such as useless (trivial), only news, basic, logical, or fundamental. Perhaps saying "'useless' knowledge [is] such as which is the third, or the thirteenth, longest river in the world," (Gregory, 2004, knowledge) is a bit harsh, and trivial is a better categorization. News contains knowledge and is better on a scale of actionable value than trivial facts. Logical and fundamental are two measures tracing back to Aristotle's Epistémé and Sophía.

While originally the levels of Bloom's Taxonomy were considered progressions that need to take place in learning, later articles (possibly partly in response to Marzano and Kendall's (2007) and Fink's (2013)) implications) state the opposite (Krathwohl, 2002, p. 218; Seaman, 2011, p. 37). While extrathesis is placed in the knowledge concept map above all three parts of the taxonomy, it may not be really different from synthesis as in some perspectives, as in this article where the authors suggest wisdom is not different from knowledge - it is merely insightful knowledge.

Discussions about the KM data, information, knowledge, and wisdom (DIKW) hierarchy appropriateness continue. ${ }^{11}$ Wisdom as insightful knowledge may be a good model for extrathesis as a special kind of synthesis. In that case, would synthesis need to be in each of the taxonomies? Or, does adapting for the Psychomotor Domain and actualizing for the Affective Domain, capture the synthezising idea?

The knowledge concept map shows ... new ideas [developed in this article] such as comprehensible/ incomprehensible, knowlike and know-valid, and vericate. [Figure 6 (the concept map)] presents a picture of how the authors see relationships between

\footnotetext{
11 "Wisdom is the combination of knowledge and experience, but it is more than just the sum of these parts" (Bennet \& Bennet, 2014, p. 27). In the same book, Williams (2014) provides a graphic that shows wisdom is at the top-right of Devon, Horme, and Cronenweth's (1988) knowledge spectrum (event $\rightarrow$... wisdom); however, he continues, "there are more critics of the DIKW hierarchy than there are exponents of it" (p. 83 \& 85) (as part of an introduction to other alternatives and his "better" suggestion). Lewis, (2013) eschewing wisdom, takes the position that information is a signal that contain both data and knowledge and that data plus knowledge is needed for decision-making.
} 
[these different viewpoints]. By example, it provides visibility to the 8 Degrees of Reason ${ }^{\mathrm{TM}}$ (Lewis, 2015a) and places the Bennets' knowledge categories in relation to other concepts. (Sisson \& Ryan, 2015, p. 1031).

\begin{tabular}{|c|}
\hline Knowledge \\
\hline Knowing \\
Truth \\
Justified \\
States \\
Expertise \\
\hline
\end{tabular}

Figure 7. Principal knowledge attributes

Source: extract from Sisson \& Ryan (2015, p. 1030).

\section{CONCLUSION}

The knowledge concept map confirms "knowledge is a multifaceted concept with multilayered meanings" (Nonaka, 1994, p. 15) with many knowledge concepts using the eleven knows and knowledge principal attributes (Figure 7) as focusing points. It substantiates that from epistemology, broadly, knowledge exists in the minds of people, may exist internally from birth, can be displayed in behavior, derives from experience perceived from the senses, is created by reasoning, may be a logically true proposition, may represent truth/reality, and "justified" knowledge can have degrees of certainty. It clarifies that "knowledge in people has been [shown] (Bloom) to be related to thoughts, as well as the kinetic nature of physical skills or feelings." The map shows that "philosophical opposing views about whether knowledge is innate or experiential" (Sisson \& Ryan, 2015, p. 1031) is a knowledge sub state (innate and experienced). Truth (certain or with certitude) is discussed (both validity and propositional states).

The paper brings forth and extends the idea that knowledge attributes can be expressed in many dimensions, sometimes as a range within a category. By example, opinions and beliefs in the certainty/certitude area could be on a scale from ' 'I' feel; 'I' think; 'I' believe; [to] 'I' know" (Atkinson, 2015, para. 3) (hopefully indicating that the transition from belief to knowing is based on some assessment of truth). The knowledge concept map shows ideas developed in this article: comprehensible / incomprehensible, knowlike, know-valid, know-competent, know-value, and vericate have a place in a general understanding about knowledge. It integrates the 8 Degrees of Reason ${ }^{\mathrm{TM}}$ (Lewis, 2015a) and places the Bennets' knowledge categories 
in relation to other relevant concepts. It implies (Figure 7) that while many knowledge attribute suggestions can be found (Alavi \& Leidner, 2001; Holsapple \& Joshi, 2004), the principal knowledge attributes are knowing, truth, justified, states, and expertise.

The theoretical sampling and theoretical saturation methods applied do not guarantee all appropriate concepts have been identified. Given the breadth, depth, and dimensionality of concepts of knowledge, later researchers may add additional concepts.

One area for additional investigation could be revelation in regards to recognition-discovery. "All knowledge comes from God" (Butts, 1958, p. 117; Heck, 2013, p. 301). Or as, another Islamic thinker, "Syed Muhammad Naquib Al-Attas" "asserts that as far as the sources and methods of knowledge are concerned, all knowledge comes from God and is acquired through the channels of the sounds senses, true reports based on authority, sound reason and intuition" (Yousif, 2001, p. 87). So, does knowledge from God through revelation mean that while revelation fits within as a perception concept, the recognition-discovery common concept needs to be unbundled (recognition and discover versus recognition-discover) - recognition (remember, recall, etc.) and discovery (find, intuit, illumination, epiphany, revelation, insight (the event)?

"Other areas to consider include know-like. Does thinking of know-like as familiarity help with psychology's difficulty explaining acquaintanceship? Would changing the acquaintanceship to know-like or familiarity help?" (Sisson \& Ryan, 2015, p. 1032). Do Gardner's existential and spiritual intelligence ideas indicate knowing other than like or being distributed across the other knows? Is know-like (perception) a way to address Gardner's (rejected) spiritual intelligence? Are know-who and know-where as generic as displayed in Table 3 ?

If one postulates a propositional awareness sequence of feel, think, believe, know; how does the idea of faith ${ }^{12}$ affect the sequence? Does the order of religious propositional states differ - perhaps, feel, think, know, and believe? Do two such propositional statement sequences indicate a fundamental difference between mundane and religious validity (the order of believe and know)?

Expanding the list of knowledge locations (such as enclouded, etc.) (Schmitt, 2015) brought up in the methodology section, Lewis's (2015c) Symbiotic Table of Knowledge $^{\mathrm{TM}}$, organizational knowledge specific attributes, and how knowledge is created, are also ideas for potential further investigations to see if they offer new insights that merit integration into the

12 "Faith almost always implies certitude even where there is no evidence or proof" (Merriam-Webster, 2012-2016, belief). 
concept map as a general mental model of knowledge. Option Outlines ${ }^{\mathrm{TM}}$ to document decisions (Lewis, 2015b) merits further investigation as a separate topic. Extrathesis's implications in understanding knowledge creation (intuition) also merit further investigation. In addition, Sisson and Mazzuchi (2017) suggest that justification, in addition to "validation, verication, and verification" could include "methodification (qualitative research approaches validation), or provisionalization (statistics)" (p. 4.), which would be another, minor addition to the concept map.

For investigators into $\mathrm{KM}$, or knowledge in management, innovation, or entrepreneurship, the knowledge concept map reveals the broad scope of knowledge that needs addressing, a truly common description of KM, and facets that can be important in other venues.

Seeing relationships of these concepts (Figure 6) helps relate many viewpoints on and about knowledge as an explicit, shareable image. The concept map provides a starting point for other investigators to use [and] explore different relationships or add other concepts (Sisson \& Ryan, 2015, p. 1032).

\section{Acknowledgements}

We thank Dr. Thomas A. Mazzuchi for his contribution of both the planning for, and completion of requested revisions.

\section{References}

Alavi, M., \& Leidner, D.E. (2001). Review: Knowledge management and knowledge management systems: Conceptual foundations and research issues. MIS Quarterly, 25(1), 107-136.

Allen, R. (Ed.). (2008). Pocket Fowler's modern English usage, ( $2^{\text {nd }}$ ed.). Oxford, UK: Oxford University Press. Retrieved from http://www. oxfordreference.com/view/10.1093/acref/9780199232581.001.0001/ acref-9780199232581

Altheide, D.L., \& Snow, R.P. (1979). Media logic. Beverly Hills, CA: Sage.

Ankh. (2016). Retrieved from https://commons.wikimedia.org/wiki/ Category:Ankh_drawings\#/media/File:Ankh1.png

Anonymous Reviewer. (2017). An economic based view on knowledge.

Armstrong, J. R. (2011). Validation: Losing its differentiation from verification?. Paper presented at the 21st Annual International Symposium of the International Council on Systems Engineering, Denver, CO.

Atherton, J.S. (2013). Bloom's taxonomy. Learning and teaching, Retrieved from http://web.archive.org/web/20160315163626/http://www.lear ningandteaching.info/learning/bloomtax.htm 
Atkinson, W.W. (2015). The secret of success - the individual. Retrieved from http://www.psitek.net/pages/PsiTekTSOS2.html

Australian Oxford dictionary. (2004). ( $2^{\text {nd }}$ ed.). Oxford, UK: Oxford University Press. Retrieved from http://www.oxfordreference.com/view/10.1093/ acref/9780195517965.001.0001/acref-9780195517965

Ayto, J., \& Crofton, I. (2011). Unknown unknowns. In J. Ayto \& I. Crofton (Eds.), Brewer's dictionary of modern phrase \& fable. Retrieved from http://www. oxfordreference.com/view/10.1093/acref/9780199916108.001.0001/ acref-9780199916108-e-8337

Bach, K. (2005). Reliabilism. In T. Honderich (Ed.), The Oxford companion to philosophy. Retrieved from http://www.oxfordreference.com. proxygw.wrlc.org/view/10.1093/acref/9780199264797.001.0001/acref9780199264797-e-2182

Bellamy, C. (2001). Sun-Tzu. In R. Holmes, C. Singleton \& D. S. Jones (Eds.), The Oxford Companion to military history. Retrieved from http://www.oxfordreference.com.proxygw.wrlc.org/view/10.1093/ acref/9780198606963.001.0001/acref-9780198606963

Bennet, A., \& Bennet, D. (2011). Laying the groundwork for a KM professional. KMEF Webinars. Retrieved July 13, 2013 from http://kmatkent.cim3. net/file/work/KMEF/KMEF-webinar_2011-03-22/KMEF-Presentation-AlexBennet-DavidBennet 20110322 v2.pdf

Bennet, A., \& Bennet, D. (2014). Knowledge, theory and practice in knowledge management: Between associative patterning and context-rich action. Journal of Entrepreneurship Management and Innovation, 1(10), 7-55.

Bennet, A., Bennet, D., \& Avedisian, J. (2015). The Course of Knowledge. Frost, WV: MQIPress.

Bennet, A., Bennet, D., \& Lewis, J. (2015). Leading with the future in mind: Knowledge and emergent leadership. Frost, WV: MQIPress.

Bennet, A., \& Porter, D. (2003). The force of knowledge: A case study of KM implementation in the Department of the Navy. In C.W. Holsapple (Ed.), Handbook on Knowledge Management (pp. 467-487). Retrieved from http://www.iwp.jku.at/born/mpwfst/03/0310forceofklch53.pdf

Bennet, A., \& Tomblin, M. S. (2006). A learning network framework for modern organizations. VINE, 36(3), 289-303.

Bennet, D., \& Bennet, A. (2008). The depth of knowledge: Surface, shallow or deep? VINE, 38(4), 405-420.

Bennet, D., \& Bennet, A. (2011). Social learning from the inside out: The creation and sharing of knowledge. In J. P. Girard \& J. L. Girard (Eds.), Social Knowledge: Using Social Media to Know What You Know. Retrieved January 26, 2015 from http://citeseerx.ist.psu.edu/viewdoc/download? doi $=10.1 \cdot 1 \cdot 206.5160 \&$ rep $=$ rep $1 \&$ type $=$ pdf

Bilbro, J. W. (2012). Risk vs. Uncertainty - cost risk vs. program risk. NASA provided by email: JB Consulting International.

Blackburn, S. (Ed.). (2008-2016). The Oxford dictionary of philosophy, $\left(2^{\text {nd }} \& 3^{\text {rd }}\right.$ ed.). Oxford, UK: Oxford University Press. Retrieved from 
http://www.oxfordreference.com.proxygw.wrlc.org/view/10.1093/ acref/9780199541430.001.0001/acref-9780199541430

Blackler, F. (1995). Knowledge, knowledge work and Organizations: An overview and interpretation. Organization Studies, 16(6), 1021-1046.

Bodner, G. M. (1986). Constructivism: A theory of knowledge. Retrieved from https://www.researchgate.net/publication/234698117_Constructivism_A_ Theory_of_Knowledge

Brockmöller, A., A.C. (2008). Knowledge sharing in expert-apprentice relations: Design of a protocol (Doctoral dissertation). University of Groningen, Enschede, NL. Retrieved from http://dissertations.ub.rug.nl/ FILES/faculties/feb/2008/a.a.c.brockmoeller/12_thesis.pdf

Brown, H. I. (2005). Innate ideas. In T. Honderich (Ed.), The Oxford Companion to Philosophy. Retrieved from http://www.oxfordreference.com. proxygw.wrlc.org/view/10.1093/acref/9780199264797.001.0001/acref9780199264797-e-1231

Buchanan, I. (Ed.). (2010-2016). A Dictionary of Critical Theory. Oxford, UK: Oxford University Press. Retrieved from http://www. oxfordreference.com/view/10.1093/acref/9780199532919.001.0001/ acref-9780199532919

BusinessDirectory.com. (2012). Retrieved from http://www. businessdictionary.com/ http://www.businessdictionary.com/

Butts, R. F. (1958). What image of man should public education foster. Religious Education, 53(2), 114-120.

Calhoun, C. (Ed.). (2002). Dictionary of the social sciences. Oxford, UK: Oxford University Press. Retrieved from http://www.oxfordreference. com.proxygw.wrlc.org/view/10.1093/acref/9780195123715.001.0001/ acref-9780195123715

Casullo, A. (2006). Knowledge, a priori. In D.M. Borchert (Ed.), Encyclopedia of Philosophy, Vol. 5. Retrieved from http://go.galegroup.com.proxygw. wrlc.org/ps/i.do?id=GALE\%7CCX3446801030\&v=2.1\&u=wash74137\&it $=r \& p=G V R L \& s w=w$

Chaharbaghi, K., Adcroft, A., Willis, R., Jasimuddin, S.M., Klein, J. H., \& Connell, C. (2005). The paradox of using tacit and explicit knowledge: Strategies to face dilemmas. Management Decision, 43(1), 102-112.

Chandler, D., \& Munday, R. (Eds.). (2011). A Dictionary of Media And Communication. Oxford, UK: Oxford University Press. Retrieved from http://www.oxfordreference.com/view/10.1093/ acref/9780199568758.001.0001/acref-9780199568758

Cohen, M. (2005). Induction. In T. Honderich (Ed.), The Oxford companion to philosophy. Retrieved from http://www.oxfordreference.com. proxygw.wrlc.org/view/10.1093/acref/9780199264797.001.0001/acref9780199264797-e-1217

Collins, H.M. (1993). The structure of knowledge. Social Research, 60(1), 95116. 
Colman, A. M. (Ed.). (2009-2016). A Dictionary of Psychology, (3 ${ }^{\text {rd }} \& 4^{\text {th }}$ ed.). Oxford, UK: Oxford University Press. Retrieved from http://www. oxfordreference.com/view/10.1093/acref/9780199534067.001.0001/ acref-9780199534067

Conee, E., \& Feldman, R. (2006). Epistemology. In D.M. Borchert (Ed.), Encyclopedia of Philosophy, Vol. 3. Retrieved from http://go.galegroup. $\mathrm{com} / \mathrm{ps} / \mathrm{i} . \mathrm{do}$ ? $\mathrm{p}=\mathrm{GVRL} \& \mathrm{sw}=\mathrm{w} \& \mathrm{u}=\mathrm{wash} 74137 \& \mathrm{v}=2.1 \& \mathrm{id}=\mathrm{GALE} \% 7 \mathrm{CCX} 34$ 46800579\&it=r\&asid=1a19836dcc54da3648af5ea8a3393cf1

Choo, C.W. (2002). Sensemaking, knowledge creation, and decision making: organizational knowing as emergent strategy. In C.C.W \& N. Bontis (Eds.), The Strategic Management of Intellectual Capital and Organizational Knowledge (pp. 79-88). Retrieved from http://choo.fis.utoronto.ca/OUP/ chooOUP/

Crane, L. (2013). A New Taxonomy of Knowledge Management Theory and the Turn to Knowledge as Constituted in Social Action. Retrieved from http://www.tlainc.com/articl332.htm

Dalkir, K. (2011). Knowledge Management in Theory and Practice [Kindle version]. Retrieved from Amazon.com

Darity, W.A., Jr. (2008). Empiricism. In W.A. Darity, Jr. (Ed.), International Encyclopedia of the Social Sciences, Vol. 2. Retrieved from http:// go.galegroup.com/ps/i.do?id=GALE\%7CCX3045300711\&v=2.1\&u=was h74137\&it=r\&p=GVRL\&sw=w\&asid=c3489949b7b9fcbf51ed612dca3c9 od9

Darvill, T. (Ed.). (2008). The Concise Oxford Dictionary of Archaeology, $\left(2^{\text {nd }}\right.$ ed.). Oxford, UK: Oxford University Press. Retrieved from http://www.oxfordreference.com.proxygw.wrlc.org/view/10.1093/ acref/9780199534043.001.0001/acref-9780199534043-e-168

Defense Acquisition Guidebook. (2013). Fort Belvoir, VA: DoD. Retrieved January 22, 2016 from https://acc.dau.mil/CommunityBrowser. aspx?id=289207\&lang=en-US

Denzin, N.K., \& Lincoln, Y.S. (Eds.). (2011). The SAGE Handbook of Qualitative Research [Kindle version]. Retrieved from Amazon.com

Doorey, M. (2004). Psychology. In K.L. Lerner \& B.W. Lerner (Eds.), The Gale Encyclopedia of Science, Vol. 5. Retrieved from http://go.galegroup.com. proxygw.wrlc.org/ps/i.do?id=GALE\%7CCX3418501863\&v=2.1\&u=wash7 4137\& $i t=r \& p=G V R L \& s w=w$

Dreyfus, H.L., \& Dreyfus, S.E. (2005). Peripheral vision: Expertise in real world contexts. Organization Studies, 26(5), 779-792.

Ein-Dor, P. (2011). Taxonomies of knowledge. In D.G. Schwartz \& D. Te'eni (Eds.), Encyclopedia of Knowledge Management, Vol. 2. Retrieved from http://go.galegroup.com/ps/i.do?id=GALE\%7CCX1786800155\&v=2.1\&u $=$ wash74137\&it=r\&p=GVRL\&sw=w\&asid=3d4a0ffb00270175dae34a47a a1d990a 
Encyclopaedia Britannica academic. (2012-2016). Chicago, IL: Encyclopaedia Britannica. Retrieved from http://academic.eb.com.proxygw.wrlc.org/ bps/browse-alpha

Fantl, J. (2012). Knowledge how. In E.N. Zalta (Ed.), The Stanford Encyclopedia of Philosophy. Retrieved from http://plato.stanford.edu/archives/ win2012/entries/knowledge-how/

Feldman, S., \& Ferrari, F. (2005). Aristotle. In L. Jones (Ed.), Encyclopedia of Religion, Vol. 1. Retrieved from http://go.galegroup.com/ps/i.do?id=GA LE\%7CCX3424500196\&v=2.1\&u=wash74137\&it=r\&p=GVRL\&sw=w\&asi $\mathrm{d}=\mathrm{f2d17aaa62928ff163ffca15190987 \textrm {aa }}$

Fink, D., \& Disterer, G. (2011). Knowledge management in professional service firms. In D.G. Schwartz \& D. Te'eni (Eds.), Encyclopedia of Knowledge Management, Vol. 1. Retrieved from http://go.galegroup.com/ps/i.do? $p=G V R L \& s w=w \& u=w a s h 74137 \& v=2.1 \& i d=G A L E \% 7 C C X 1786800075 \& i t=$ r\&asid=4c76ed485efdaa5582614c569cd52bb3

Fink, L.D. (2013). What is 'significant learning'?. Retrieved from http://www. wcu.edu/WebFiles/PDFs/facultycenter_SignificantLearning.pdf

Foxwell, H.J. (2013). Machines only human too. Humanist, 73, 5-5.

Gardner, H. (2000). A case against spiritual intelligence. International Journal for the Psychology of Religion, 10(1), 27-34.

Geisler, E., \& Wickramasinghe, N. (2015). Principles of Knowledge Management: Theory, practice, and cases [Kindle version]. Retrieved from Amazon.com

Gimbel, S. (2011). Exploring the Scientific Method: Cases and Questions. Chicago, IL: University of Chicago Press.

Ginet, C. (2006). Volition. In D.M. Borchert (Ed.), Encyclopedia of Philosophy, Vol. 9. Retrieved from http://go.galegroup.com/ps/i.do?id=GALE\%7CCX $3446802097 \& v=2.1 \& u=w a s h 74137 \& i t=r \& p=G V R L \& s w=w \& a s i d=2 d 512$ 6937d8b2e924c9c2085edd8ed55

Green, A. (2005). A framework of intangible valuation areas (FIVA): Aligning intangible assets with business strategy. Creating the discipline of knowledge management - Chat with the authors. Institute for Knowledge and Innovation.

Green, A., \& Ryan, J., J.C.H. (2005). A framework of intangible valuation areas (FIVA): Aligning business strategy and intangible assets. Journal of Intellectual Capital, 6(1), 43-52.

Gregory, R. L. (2004). The Oxford companion to the mind. Retrieved from http://www.oxfordreference.com.proxygw.wrlc.org/view/10.1093/ acref/9780198662242.001.0001/acref-9780198662242

Gustavsson, K. (2014). Charlie Dunbar Broad. In E.N. Zalta (Ed.), The Stanford Encyclopedia of Philosophy. Retrieved from http://plato.stanford.edu/ archives/win2014/entries/broad/

Heck, P. L. (2013). Knowledge. In G. Bowering (Ed.), The Princeton Encyclopedia of Islamic Political Thought. Retrieved from http://go.galegroup.com/ 
ps/i.do?id=GALE\%7CCX1510900228\&v=2.1\&u=wash74137\&it=r\&p=GV RL\&sw=w\&asid=d6b448159dc3113d9804d9da87289317

Heery, E., \& Noon, M. (Eds.). (2008). A Dictionary of Human Resource Management, (2 rev ed.). Oxford, UK: Oxford University Press. Retrieved from http://www.oxfordreference.com/view/10.1093/ acref/9780199298761.001.0001/acref-9780199298761

Heil, J. (2005). Epistemology and psychology. In T. Honderich (Ed.), The Oxford Companion to Philosophy. Retrieved from http://www.oxfordreference. com.proxygw.wrlc.org/view/10.1093/acref/9780199264797.001.0001/ acref-9780199264797-e-764

Holsapple, C.W., \& Joshi, K.D. (2004). A formal knowledge management ontology: Conduct, activities, resources, and influences. Journal of the American Society for Information Science and Technology, 55(7), 593-612.

InPhOrmers. (2014). Indiana philosophy ontology (INPHO) project. Retrieved from https://inpho.cogs.indiana.edu/

Kazmer, M.M. (2002). Information industry. In J.R. Schement (Ed.), Encyclopedia of Ccommunication and Information, Vol. 2. Retrieved from http://go.galegroup.com/ps/i.do?id=GALE\%7CCX3402900130\&v=2.1\&u $=w a s h 74137 \& i t=r \& p=G V R L \& s w=w \& a s i d=9 d a d b 0539773 f 60 f 5 d 665 e b 8$ $4 a 9 b c 92 c$

Kelly, K. (2014a, October 27). The three breakthroughs that have finally unleashed Al on the world. Wired. Retrieved from http://www.wired. com/2014/10/future-of-artificial-intelligence/

Kelly, K. (2014b). What is the early path of commercialization for artificial intelligence? What will be Al's first killer apps?. Reinventors: Reinvent Artificial Intelligence. Retrieved from http://reinventors.net/roundtables/ reinvent-artificial-intelligence/?utm_content=buffer0365b\&utm _ medium=social\&utm_source=twitter.com\&utm_campaign=buffer

Kent, M. (Ed.). (2007-2016). The Oxford Dictionary of Sports Science \& Medicine. Oxford, UK: Oxford University Press. Retrieved from http://www.oxfordreference.com.proxygw.wrlc.org/view/10.1093/ acref/9780198568506.001.0001/acref-9780198568506

Kidd, I. G. (2006). Greek academy. In D.M. Borchert (Ed.), Encyclopedia of Philosophy, Vol. 4. Retrieved from http://go.galegroup.com/ps/i.do?id= GALE\%7CCX3446800769\&v=2.1\&u=wash74137\&it=r\&p=GVRL\&sw=w\& asid $=26218$ dfadea50ea41e3b5203b0890c2c

Klein, P. (2014). Skepticism. In E.N. Zalta (Ed.), The Stanford Encyclopedia of Philosophy. Retrieved from http://plato.stanford.edu/archives/ sum2013/entries/skepticism/

Koenig, M.E. (2012, May 4). What is KM? Knowledge management explained. KMWorld Magazine. Retrieved from http://www.kmworld.com/ Articles/Editorial/What-Is-../What-is-KM-Knowledge-ManagementExplained-82405.aspx?iframe $=$ true\&width $=90 \%$ \& height $=90 \%$

Krathwohl, D. R. (2002). A revision of bloom's taxonomy: An overview. Theory into Practice, 41(4), 212-218. 
Krathwohl, D.R., Bloom, B.S., \& Masia, B.B. (1964). Taxonomy of Educational Objectives, Handbook II: Affective Domain. New York, NY: David McKay.

Krueger, M., Walden, D., \& Hamelin, R.D. (2011). Systems engineering handbook - a guide for system life cycle processes and activities ( $v$. 3.2.1). Retrieved from http://www.incose.org/ProductsPubs/products/ sehandbook.aspx

Lacey, A. (2005a). Empiricism. In T. Honderich (Ed.), The Oxford Companion to Philosophy. Retrieved from http://www.oxfordreference.com. proxygw.wrlc.org/view/10.1093/acref/9780199264797.001.0001/acref9780199264797-e-730? rskey=2bhROd\&result $=721$

Lacey, A. (2005b). Rationalism. In T. Honderich (Ed.), The Oxford Companion to Philosophy. Retrieved from http://www.oxfordreference.com. proxygw.wrlc.org/view/10.1093/acref/9780199264797.001.0001/acref9780199264797-e-2126?rskey=Yh4SGS

Last, J. M. (Ed.). (2007). A Dictionary of Public Health. Oxford, UK: Oxford University Press. Retrieved from http://www.oxfordreference.com. proxygw.wrlc.org/view/10.1093/acref/9780195160901.001.0001/ acref-9780195160901

Leff, M. C. (1983). The topics of argumentative invention in Latin rhetorical theory from cicero to boethius. Rhetorica: A Journal of the History of Rhetoric, 1(1), 23-44.

Leonard, D., \& Swap, W. (2004). Deep smarts. Engineering Management Review, IEEE, 32(4), 3-10.

Lewis, J. (2012). The Explanation Age. United States.

Lewis, J. (2013). The Explanation Age. United States.

Lewis, J. (2015a). 8 Degrees of Reason ${ }^{\mathrm{TM}}$. Retrieved from http://www. explanationage.com/8-degrees-of-reason.html

Lewis, J. (2015b). Option Outline ${ }^{\mathrm{TM}}$. Retrieved from http://www. explanationage.com/option-outline.html

Lewis, J. (2015c). The Symbiotic Table of Knowledge ${ }^{\mathrm{TM}}$. Retrieved from http:// www.explanationage.com/the-symbiotic-table-of-knowledge.html

Li, X. (2012). Sun Zi (Sun-Tzu, 535-496 bc). In X. Li (Ed.), China at War: An Encyclopedia. Retrieved from http://go.galegroup.com/ps/i.do?id=GALE $\% 7 C C X 2721600204 \& v=2.1 \& u=w a s h 74137 \& i t=r \& p=G V R L \& s w=w \& a s i d=$ 26c8080682da573dac80e3b36549d8f6

Lowenthal,P., \&Muth, R.(2008). Constructivism.InE.F.Provenzo\&A.B.Provenzo (Eds.), Encyclopedia of the Social and Cultural Foundations of Education. http://dx.doi.org.proxygw.wrlc.org/10.4135/9781412963992.n86

Macmillan dictionary. (2105, January 24, 2015). Known unknown. Retrieved from http://www.macmillandictionary.com/us/open-dictionary/entries/ known-unknown.htm

Magalis, E. (2005). Keys. In L. Jones (Ed.), Encyclopedia of Religion, Vol. 8. Retrieved from http://go.galegroup.com/ps/i.do?id=GALE\%7CCX34245 $01709 \& v=2.1 \& u=w a s h 74137 \& i t=r \& p=G V R L \& a s i d=9472 d a 2396521636$ $6147516 \mathrm{e} 82401344$ 
Markie, P. (2013). Rationalism vs. Empiricism. In E.N. Zalta (Ed.), The Stanford Encyclopedia of Philosophy. Retrieved from http://plato.stanford.edu/ archives/sum2015/entries/rationalism-empiricism/

Marquardt, M.J. (2002). Building the Learning Organization: Mastering the 5 Elements for Corporate Learning. Available from https://www.ebscohost. com/ebooks

Martinich, A.P., \& Stroll, A. (2013). The nature of epistemology. In A.P. Martinich (Ed.), Encyclopædia Britannica online academic edition. Retrieved from http://www.britannica.com.proxygw.wrlc.org/topic/epistemology

Marzano, R. J., \& Kendall, J. S. (2007). The new taxonomy of educational objectives [Kindle version]. Retrieved from Amazon.com

Matthews, P.H. (Ed.). (2007-2014). The Concise Oxford Dictionary of Linguistics, ( $2^{\text {nd }} \& 3^{\text {rd }}$ ed.). Oxford, UK: Oxford University Press. Retrieved from http://www.oxfordreference.com.proxygw.wrlc.org/view/10.1093/ acref/9780199202720.001.0001/acref-9780199202720

Maxwell, R. W. (2009). The physiological foundation of yoga chakra expression. Zygon, 44(4), 807-824.

McFarland, D. (Ed.). (2006). A Dictionary of Animal Behaviour ( $2^{\text {nd }}$ ed.). Oxford, UK: Oxford University Press. Retrieved from http://www.oxfordreference. com.proxygw.wrlc.org/view/10.1093/acref/9780191761577.001.0001/ acref-9780191761577

Merriam-Webster. (2011-2016). Merriam-Webster Thesaurus, Britannica Academic Edition) Encyclopædia Britannica. Retrieved from http:// academic.eb.com/bps/thesaurus?query=search

Merriam-Webster. (2012-2016). Merriam-Webster Dictionary, Britannica Academic Edition) Chicago, IL: Encyclopædia Britannica. Retrieved from http://academic.eb.com/bps/dictionary

Merriam-Webster. (2013-2017). Webster's Third New International Dictionary, Unabridged) Springfield, MA: Merriam-Webster. Retrieved from http:// unabridged.merriam-webster.com/

NASA SEH. (2007). NASA Systems Engineering Handbook (nasa/sp-2007-6105, rev. 1). (NASA/SP-2007-6105). Washington. DC: National Aeronautics and Space Administration. Retrieved from http://ntrs.nasa.gov/archive/ nasa/casi.ntrs.nasa.gov/20080008301.pdf

Nichols, F. (2000). The knowledge in knowledge management. In J.W. Cortada \& J.A. Woods (Eds.), The Knowledge Management Yearbook. Retrieved from http://www.nickols.us/knowledge_in_KM.pdf

Nonaka, I. (1994). A dynamic theory of organizational knowledge creation. Organization Science, 5(1), 14-37.

Nuzzi, R.J. (2010). Multiple intelligences. In T. Hunt, J. Carper, T. Lasley \& C. Raisch (Eds.), Encyclopedia of Educational Reform and Dissent. Retrieved from http://dx.doi.org.proxygw.wrlc.org/10.4135/9781412957403.n280 O'Connor, B. (2003). Space Shuttle Return to Flight (the safety guy's view). NASA provided by email: Office of Safety and Mission Assurance. 
Omotayo, F. O. (2015). Knowledge management as an important tool in organisational management: A review of literature. Retrieved from http://digitalcommons.unl.edu/cgi/viewcontent.cgi?article=3330\&cont ext=libphilprac

Österberg, P. (2004). Generative learning management: A hypothetical model. The Learning Organization, 11(2), 145-158.

Oxford English Dictionary. (2011-2017). Oxford, UK: Oxford University Press. Retrieved from http://www.oed.com

Parry, R. (2008). Episteme and techne. In E.N. Zalta (Ed.), The Stanford Encyclopedia of Philosophy. Retrieved from http://plato.stanford.edu/ archives/fall2008/entries/episteme-techne/

Pike, N. (2005). Empiricism. In L. Jones (Ed.), Encyclopedia of Religion, Vol. 4. Retrieved from http://go.galegroup.com/ps/i.do?id=GALE\%7CCX34245 $00924 \& v=2.1 \& u=w a s h 74137 \& i t=r \& p=G V R L \& s w=w \& a s i d=e d 5 b 922 b e 7 c$ 19cb7f0d8484d779be0dd

Plucker, J.A., \& Esping, A. (2014). Multiple intelligences: Howard Gardner. In D.C. Phillips (Ed.), Encyclopedia of Educational Theory and Philosophy. Retrieved from http://dx.doi.org.proxygw.wrlc. org/10.4135/9781483346229.n229

Pompper, D. (2005). Straight news. In R.L. Heath (Ed.), Encyclopedia of Public Relations, Vol. 2. Retrieved from http://go.galegroup.com/ps/i.do?id=G ALE\%7CCX3439100417\&v=2.1\&u=wash74137\&it=r\&p=GVRL\&sw=w\&as id $=$ c82f21e4cbfa590fe47a96acfe8db8be

Quinn, J.B., Anderson, P., \& Finkelstein, S. (1996). Managing professional intellect: Making the most of the best. Harvard Business Review, 74(2), 71-80.

Quinton, A.M., Quinton, B., \& Fumerton, R. (2013). Empiricism. In Encyclopædia Britannica online academic edition. Retrieved from http:// www.britannica.com. proxygw.wrlc.org/topic/empiricism

Reed, B. (2011). Certainty. In E.N. Zalta (Ed.), The Stanford Encyclopedia of Philosophy. Retrieved from http://plato.stanford.edu/archives/win2011/ entries/certainty/

Reines, A. J. (2007). Skeptics and skepticism. In M. Berenbaum \& F. Skolnik (Eds.), Encyclopaedia Judaica, Vol. 18. Retrieved from http:// go.galegroup.com/ps/i.do?id=GALE\%7CCX2587518685\&v=2.1\&u=was h74137\&it=r\&p=GVRL\&sw=w\&asid=bcc51012406000917ddd93d6f95d $1 \mathrm{~d} 57$

Ruban, L.M., \& Cantu, C.A. (2005). Multiple intelligences. In N.J. Salkind (Ed.), Encyclopedia of Human Development. Retrieved from http://knowledge. sagepub.com.proxygw.wrlc.org/view/humandevelopment/n424.xml

Ryan, S. (2014). Wisdom. In E.N. Zalta (Ed.), The Stanford Encyclopedia of Philosophy. Retrieved from http://plato.stanford.edu/archives/win2014/ entries/wisdom 
Schmitt, U. (2013). Managing personal knowledge to make a difference. Paper presented at the 27th British Academy of Management Conference Proceedings (BAM).

Schmitt, U. (2015). Faqs and navigational guide to PKM articles, papers, and posters with short abstracts (oct 2015). Retrieved from https://www. researchgate.net/publication/282852852_FAQs_and_Navigational_ Guide_to_PKM_Articles_Papers_and_Posters_with_short_Abstracts_ Oct_2015

Schwandt, D., \& Gundlach, A. (1992). Organizational learning: The development and implementation of an operational systems model. [unpublished manuscript]. George Washington University. Washington, DC.

Schwandt, D., \& Marquardt, M. J. (2000). Organizational Learning: From World-Class Theories to Global Best Practices. Boca Raton, FL: St. Lucie Press.

Schwartz, D. G. (2011). An Aristotelian view of knowledge for knowledge management. In D. G. Schwartz \& D. Te'eni (Eds.), Encyclopedia of Knowledge Management, Vol. 1. Retrieved from http://go.galegroup. $\mathrm{com} / \mathrm{ps} / \mathrm{i}$.do?p=GVRL\&sw=w\&u=wash74137\&v=2.1\&it=r\&id=GALE\%7C CX1786800017\&asid=b277b697964ba7780daa17bab84851a9

Schwandt, D. R. (1994). Organizational learning as a dynamic sociological construct: Theory and research. Paper presented at the 10th Systems Dynamics Society Meeting, Edinburgh, Scotland.

Schwarzschild, S. S. (2007). Truth. In M. Berenbaum \& F. Skolnik (Eds.), Encyclopaedia Judaica, Vol. 20. Retrieved from http://go.galegroup.com. proxygw.wrlc.org/ps/i.do?id=GALE\%7CCX2587520070\&v=2.1\&u=wash7 4137\&it=r\&p=GVRL\&sw=w\&authCount $=1 \#$

Scott, J., \& Marshall, G. (Eds.). (2009-2015). A Dictionary of Sociology, ( $3^{\text {rd }}$ rev. ed.). Oxford, UK: Oxford University Press. Retrieved from http://www. oxfordreference.com/view/10.1093/acref/9780199533008.001.0001/ acref-9780199533008

Seaman, M. (2011). Bloom's taxonomy: Its evolution, revision, and use in the field of education. Curriculum and Teaching Dialogue, 13(1/2), 29-131A.

Senge, P.M., Kleiner, A., Roberts, C., Ross, R.B., \& Smith, B.J. (1994). The Fifth Discipline Fieldbook. Strategies and Tools for Building a Learning Organization. New York: Doubleday.

Serenko, A., \& Dumay, J. (2015). Citation classics published in knowledge management journals. Part I: Articles and their characteristics. Journal of Knowledge Management, 19(2), 401-431.

Sisson, P.W., \& Mazzuchi, T.A. (2017). Organic and fundamental functions: New perspective on the multidisciplinary nature of knowledge management. $18^{\text {th }}$ European Conference on Knowledge Management. Barcelona, Spain. Sisson, P.W., \& Ryan, J., J.C.H. (2015). What do we know? - building a knowledge concept map. $16^{\text {th }}$ European Conference on Knowledge Management. Udine, IT. 
Sisson, P.W., \& Ryan, J., J.C.H. (2016a). Indications of a justifiable unified theory of knowledge management. Paper presented at the $17^{\text {th }}$ European Conference on Knowledge Management. Ulster University, Northern Ireland, UK.

Sisson, P.W., \& Ryan, J., J.C.H. (2016b). Leveraging knowledge and learning to help engineer a common understanding of knowledge management using a re-architecture approach [presentation]. Engineering Management and System Engineering (EMSE) Seminar. Washington, DC: School of Applied Science and Engineering, George Washington University. Retrieved from https://www.researchgate.net/publication/297219892_Leveraging_ Knowledge_and_Learning_to_Help_Engineer_A_Common_Explanation_ of_Knowledge_Management_Using_a_Re-architecture_Approach

Sisson, P.W., \& Ryan, J., J.C.H. (2016c). Poster: Leveraging knowledge and learning to help engineer a common understanding of knowledge management using a re-architecture approach. George Washington University (GWU) Research Days. Washington, DC: George Washington University. Retrieved from https://www.researchgate.net/ publication/299507114_Leveraging_Knowledge_Learning_to_Help_ Engineer_A_Common_Knowledge_Management_KM_Explanation_ Using_a_Re-architecture_Approach

Stankosky, M. (2003). Combined KM tutorial slides. EMSE 270 - Introduction to Knowledge Management. Washington, DC: George Washington University.

Stevenson, A. (Ed.). (2010-2017). Oxford dictionary of English, $\left(2^{\text {nd }} \& 3^{\text {rd }}\right.$ ed.). Oxford, UK: Oxford University Press. Retrieved from http://www. oxfordreference.com/view/10.1093/acref/9780199571123.001.0001/ acref-9780199571123

Stroll, A. (2013). Epistemology. In A.P. Martinich (Ed.), Encyclopædia Britannica online academic edition. Retrieved from http://www.britannica.com. proxygw.wrlc.org/EBchecked/topic/190219/epistemology

The Sonshi Group. (2015). Sun Tzu's the art of war. Retrieved from https:// www.sonshi.com/original-the-art-of-war-translation-not-giles.html

Thinkmap. (2012-2017). Visualthesaurus, "Image or text from the Visual Thesaurus. New York, NY: Thinkmap. Retrieved from http://www. visualthesaurus.com/

Tiles, J. (2004). Induction. In R.L. Gregory (Ed.), The Oxford Companion to the Mind. Retrieved from http://www.oxfordreference.com.proxygw. wrlc.org/view/10.1093/acref/9780198662242.001.0001/acref9780198662242-e-447

Tiles, J. E. (2004). A priori. In R.L. Gregory (Ed.), The Oxford Companion to the Mind. Retrieved from http://www.oxfordreference.com.proxygw. wrlc.org/view/10.1093/acref/9780198662242.001.0001/acref9780198662242-e-59

Ubiquity staff. (2005, February). Leonard and swap on 'deep smarts'. Ubiquity, 2005, 1-1. Retrieved from http://dl.acm.org/citation.cfm?id=1066329 
Van Gulick, R. (2011). Consciousness. In E.N. Zalta (Ed.), The Stanford Encyclopedia of Philosophy. Retrieved from http://plato.stanford.edu/ archives/sum2011/entries/consciousness/

Vaughan, F. (2002). What is spiritual intelligence?. Journal of Humanistic Psychology, 42(2), 16-33.

Waite, M., Lindberg, C.A., \& Zimmer, B.G. (Eds.). (2008). Pocket Oxford American Thesaurus. Oxford, UK: Oxford University Press. Retrieved from http://www.oxfordreference.com.proxygw.wrlc.org/view/10.1093/ acref/9780195301694.001.0001/acref-9780195301694

Waterhouse, L. (2013). Multiple intelligences theory. In H. Pashler (Ed.), Encyclopedia of the Mind. Retrieved from http://sk.sagepub.com/ reference/encyclopedia-of-the-mind/n201.xml

Whetten, D.A., \& Rodgers, Z.J. (2013). Theory development. In E.H. Kessler (Ed.), Encyclopedia of Management Theory. Retrieved from http:// dx.doi.org/10.4135/9781452276090.n261

Williams, D. (2014). Models, metaphors and symbols for information and knowledge systems. Retrieved from http://www.repozytorium.wsbnlu.edu.pl/bitstream/handle/11199/8178/Williams\%20David,\%20 Models,\%20Metaphors\%20and\%20Symbols\%20for\%20Information\%20 and\%20Knowledge\%20Systems.pdf?sequence $=1$

Wilson, S., \& Ibrahim, F. (2011). Forensic journalism: Dramatizing crime news. Paper presented at the International Conference on Language and Communication. Putrajaya, MY.

Yousif, A. F. (2001). "Islamic science": Controversies, influence and future possibilities for scientific education in Brunei Darussalam. Religious Studies and Theology, 20(1), 81-107.

\footnotetext{
Abstract (in Polish)

Celem tego artykułu jest przedstawienie mentalnego modelu wiedzy jako mapy koncepcyjnej i wkładu w badania nad zarzqdzaniem wiedza (KM). Ta koncepcja mapy rozszerzonej wiedzy może służyć jako zasób, w którym badanie, opracowywanie lub stosowanie wiedzy byłoby dostarczane z szerokim, mentalnym modelem wiedzy. Wcześniej niepowiqzane pojęcia sq łączone; pojęcia wiedzy można czasami wyrazić w pewnym zakresie, tj. w pewnych stanach, jak: pogląd, opinia, sentyment, perswazja, wiara i przekonanie. Extrathesis jest określany jako potencjalny poziom umiejętności wyższy niż synteza i zwiqzzany z pojęciami: odkrycie, instytucja, wglqad (zdarzenie), objawienie lub oświecenie poprzedzajqce innowacje. Do zebrania i dokumentowania koncepcji wykorzystano metody jakościowe. W celu zdefiniowania i powiq̨zania pojęć zastosowano inżynierię systemów i metody analizy obiektów. Jednak teoretyczne metody pobierania próbek i teoretycznego nasycenia nie gwarantujq, że wszystkie odpowiednie pojęcia zostały zidentyfikowane. Biorq̨c pod uwagę szerokość, głębokość i wymiarowość pojęć wiedzy, badacze moga dodać dodatkowe pojęcia. Artykuł dostarcza dowodów na dodatkowe rzeczy, o których wiedzq ludzie, alternatywę dla znajomości psychologii, zrozumienia i umieszczania nowszych kategoryzacji wiedzy w stosunku do starszych i sugeruje, że istniejq zakresy wiedzy. Artykut stanowi
} 
rozwinięcie artykułu z roku 2015 na ten temat: 1) pogłębiajq̨ spojrzenie na epistemologiczne pojęcia i relacje, 2) dostarczajqc kontekstowe definicje, 3) sugerujqc, że ekstrakcja jest pomysłem poza syntezq, 4) aktualizujqc mapy koncepcyjne; i 5) dostarczajqc nowego wglqdu w „wiedzieć". Artykuł zapewnia solidne podstawy do badań nad KM, zapewniajqc szerokie zrozumienie wiedzy.

Słowa kluczowe: wiedza; mapa koncepcyjna; mapa koncepcji wiedzy.

\section{Biographical notes}

Philip W. Sisson is a retired Lockheed Martin Senior Program Manager, KM cross-division coordinator, and KM best practices track leader. He is an Engineering Management (KM focus) doctoral candidate at George Washington University's School of Engineering and Applied Science. Phil has degrees in mathematics, ORSA and economics, and computer information systems.

Dr. Julie Ryan has been working in the field of information security for over 30 years. Starting out as an intelligence officer in the US Air Force, she has tackled problems in the military, in government, in industry, and in academia. Currently, she is Professor of Cybersecurity at the National Defense University, located in downtown Washington, D.C., where she teaches and directs research in information security, cyberwarfare, systems dynamics, and analytics. Her books include "Defending Your Digital Assets Against Hackers, Crackers, Spies and Thieves" (McGraw-Hill 2000), "Leading Issues in Information Warfare and Security" (API 2011), and "Detecting and Combatting Malicious Email" (Elsevier 2014). Her degrees include B.S. from the U.S. Air Force Academy, MLS from Eastern Michigan University, and D.Sc. from George Washington University. 
